\title{
Sodium-Mediated Plateau Potentials in Lumbar Motoneurons of Neonatal Rats
}

\author{
Mouloud Bouhadfane, ${ }^{1}$ Sabrina Tazerart, ${ }^{1}$ Aziz Moqrich, ${ }^{2}$ Laurent Vinay, ${ }^{1}$ and Frédéric Brocard ${ }^{1}$ \\ ${ }^{1}$ Institut de Neurosciences de la Timone (UMR7289), Aix-Marseille Université and CNRS, Marseille, France, and ${ }^{2}$ Institut de Biologie du Développement de \\ Marseille Luminy (UMR6216), Aix-Marseille Université and CNRS, Marseille, France
}

The development and the ionic nature of bistable behavior in lumbar motoneurons were investigated in rats. One week after birth, almost all $(\sim 80 \%)$ ankle extensor motoneurons recorded in whole-cell configuration displayed self-sustained spiking in response to a brief depolarization that emerged when the temperature was raised $>30^{\circ} \mathrm{C}$. The effect of L-type $\mathrm{Ca}^{2+}$ channel blockers on self-sustained spiking was variable, whereas blockade of the persistent sodium current $\left(\mathrm{I}_{\mathrm{NaP}}\right)$ abolished them. When hyperpolarized, bistable motoneurons displayed a characteristic slow afterdepolarization (sADP). The sADPs generated by repeated depolarizing pulses summed to promote a plateau potential. The sADP was tightly associated with the emergence of $\mathrm{Ca}^{2+}$ spikes. Substitution of extracellular Na ${ }^{+}$or chelation of intracellular $\mathrm{Ca}^{2+}$ abolished both sADP and the plateau potential without affecting $\mathrm{Ca}^{2+}$ spikes. These data suggest a key role of a Ca ${ }^{2+}$-activated nonselective cation conductance $\left(\mathrm{I}_{\mathrm{CaN}}\right)$ in generating the plateau potential. In line with this, the blockade of $\mathrm{I}_{\mathrm{CaN}}$ by flufenamate abolished both sADP and plateau potentials. Furthermore, 2-aminoethoxydiphenyl borate (2-APB), a common activator of thermo-sensitive vanilloid transient receptor potential (TRPV) cation channels, promoted the sADP. Among TRPV channels, only the selective activation of TRPV 2 channels by probenecid promoted the sADP to generate a plateau potential. To conclude, bistable behaviors are, to a large extent, determined by the interplay between three currents: L-type $\mathrm{I}_{\mathrm{Ca}}$, $\mathrm{I}_{\mathrm{NaP}}$, and a Na ${ }^{+}$-mediated $\mathrm{I}_{\mathrm{CaN}}$ flowing through putative TRPV2 channels.

\section{Introduction}

Locomotor movements are driven by a central pattern generator (CPG) located in the spinal cord (Grillner and Zangger, 1975). Although the CPG is functional at birth (Cazalets et al., 1990; Fady et al., 1998), rats walk later during the second postnatal week (Altman and Sudarshan, 1975; Westerga and Gramsbergen, 1990). The development of posture is the main limiting factor for locomotion (Brocard et al., 1999; Vinay et al., 2002; Clarac et al., 2004). The gradual acquisition of repetitive firing properties by motoneurons contributes to the development of postural tone (Vinay et al., 2000a).

In spinal motoneurons of adult vertebrates, self-sustained firing appears to arise from a prolonged depolarization known as "plateau potential" (Perrier and Hounsgaard, 2000; Brownstone, 2006; Heckman et al., 2008b). Plateau potentials are triggered by brief excitations and turned off by inhibitory inputs promoting a bistable behavior of the membrane potential (Hultborn et al., 1975; Schwindt and Crill, 1980; Hounsgaard et al., 1984; Crone et

Received April 5, 2013; revised Aug. 20, 2013; accepted Aug. 23, 2013.

Author contributions: M.B., A.M., L.V., and F.B. designed research; M.B., S.T., and F.B. performed research; M.B. and F.B. analyzed data; M.B., A.M., L.V., and F.B. wrote the paper.

This work and S.T. were supported by the French Institut pour la Recherche sur la Moelle Epinière et l'Encéphale (IRME to F.B. and L.V.), and the Agence Nationale pour la Recherche. S.T. received a grant from the Fondation pour la Recherche Médicale (FRM) and the Fondation Aix-Marseille Université.

The authors declare no competing financial interests.

Correspondence should be addressed to Dr Frédéric Brocard, Institut de Neurosciences de la Timone, Campus santé Timone, 27, boulevard Jean Moulin, F-13385 Marseille cx5, France. E-mail: frederic.brocard@univ-amu.fr.

DOI:10.1523/JNEUROSCI.1483-13.2013

Copyright $\odot 2013$ the authors $\quad 0270-6474 / 13 / 3315626-16 \$ 15.00 / 0$ al., 1988; Bennett et al., 1998). By means of paired motor unit recordings, correlates of such bistable behaviors have been found in vivo (Eken et al., 1989; Kiehn and Eken, 1997; Gorassini et al., 1998, 1999; Collins et al., 2001). Because these are especially observed in low-threshold motor units (Lee and Heckman, 1998), they are thought to be important in postural functions (Kiehn and Eken, 1998). Plateau potentials are contingent upon a supraspinal monoaminergic control (Conway et al., 1988; Hounsgaard et al., 1988; Hounsgaard and Kiehn, 1989; Perrier and Delgado-Lezama, 2005) and rely on persistent inward currents primarily mediated by dendritic L-type $\mathrm{Ca}^{2+}$ channels (Hounsgaard and Mintz, 1988; Hounsgaard and Kiehn, 1993; Booth and Rinzel, 1995; Carlin et al., 2000a; Heckman et al., 2003; Li and Bennett, 2003; Li et al., 2004; Bui et al., 2006; Carlin et al., 2009). In conjunction with the postnatal development of descending monoaminergic projections (Bregman, 1987; Rajaofetra et al., 1989, 1992; Vinay et al., 2000b) and that of L-type Ca ${ }^{2+}$ current (Jiang et al., 1999; Carlin et al., 2000a), the emergence of plateaus in motoneurons may parallel the acquisition of a quadrupedal stance in rats.

To test this assumption, the present study investigates the emergence of self-sustained firing in motoneurons of the triceps surae muscle that gradually acquire a tonic EMG activity during the first postnatal week (Brocard et al., 1999). We demonstrate that most motoneurons are bistable as early as birth in neonatal rat. Instead of L-type $\mathrm{Ca}^{2+}$ current, the plateau potentials responsible for self-sustained firing are primarily mediated by a $\mathrm{Ca}^{2+}$-activated nonselective cationic current $\left(\mathrm{I}_{\mathrm{CaN}}\right)$ flowing through putative transient receptor potential (TRPV) 2 channels. 


\section{Materials and Methods}

Experiments were performed on neonatal (0- to 7-d-old) Wistar rats of either sex. We housed rodents in a temperature-controlled animal-care facility with a $12 \mathrm{~h}$ light/dark cycle. We made all efforts to minimize animal suffering and the number of animals used. All surgical and experimental procedures conformed to guidelines from the French Ministry for Agriculture and Fisheries, Division of Animal Rights, and the European guidelines for the care and use of laboratory animals (Council Directive 86/6009/EEC).

Labeling of triceps surae motoneurons. The procedure to label motoneurons before slice preparation was previously described in detail (Sadlaoud et al., 2010). Briefly, in cryoanesthetized rat pups, $5 \mu \mathrm{l}$ of a solution of fluorescein-conjugated cholera toxin B subunit (Invitrogen, $0.5 \mathrm{mg} / \mathrm{ml}$ ) was injected bilaterally into the triceps surae muscles to retrogradely label gastrocnemius and soleus motoneuron pools. Animals were returned to their cages and a postinjection survival time of at least $12 \mathrm{~h}$ enabled the retrograde transport.

In vitro slice preparation. Electrophysiological experiments were performed on acute spinal cord slices. Neonatal rats were decapitated and eviscerated, and the lumbar spinal cord was isolated in ice-cold $\left(<4^{\circ} \mathrm{C}\right)$ artificial CSF (ACSF) solution composed of the following (in mM): 232 sucrose, $3 \mathrm{KCl}, 1.25 \mathrm{KH}_{2} \mathrm{PO}_{4}, 4 \mathrm{MgSO}_{4}, 0.2 \mathrm{CaCl}_{2}, 26 \mathrm{NaHCO}_{3}, 25$ D-glucose, $\mathrm{pH}$ 7.4. The lumbar spinal cord was then introduced into a $1 \%$ agar solution, quickly cooled, mounted in a vibrating microtome (Leica, VT1000S) and sliced $(350 \mu \mathrm{m})$ through the L4-5 lumbar segments. Slices were immediately transferred into the holding chamber filled with ACSF solution composed of the following (in $\mathrm{mm}$ ): $120 \mathrm{NaCl}, 3 \mathrm{KCl}, 1.25$ $\mathrm{NaH}_{2} \mathrm{PO}_{4}, 1.3 \mathrm{MgSO}_{4}, 1.2 \mathrm{CaCl}_{2}, 25 \mathrm{NaHCO}_{3}, 20$ D-glucose, pH 7.4, $\sim 30^{\circ} \mathrm{C}$. Following a $1 \mathrm{~h}$ resting period, individual slices were transferred to a recording chamber that was continuously perfused $(\sim 4 \mathrm{ml} / \mathrm{min})$ with the same medium heated to $\sim 34^{\circ} \mathrm{C}$ or with a HEPES-buffered solution [composed of the following (in mM): $145 \mathrm{NaCl}, 3 \mathrm{KCl}, 1.3 \mathrm{MgCl}_{2}$, 1.2 $\mathrm{CaCl}_{2}$, HEPES $10,20 \mathrm{D}$-glucose, $\mathrm{pH} 7.4, \sim 34^{\circ} \mathrm{C}$ ) to avoid a precipitate when tranilast, $4 \alpha \mathrm{PDD}$, lanthanum, or the gadolinium (see Drug list, below) were used. The temperature regulation was provided by the CL100 bipolar temperature controller (Warner Instruments). Slices were visualized with epifluorescence and infrared differential interference contrast microscopy using a Nikon Eclipse E600FN upright microscope coupled with a $40 \times$ water-immersion lens. The image was enhanced with a Hitachi KP-200/201 infrared-sensitive CCD camera and displayed on a video monitor. All solutions were oxygenated with $95 \% \mathrm{O}_{2} / 5 \% \mathrm{CO}_{2}$ except for the HEPES-buffered solution oxygenated with $100 \% \mathrm{O}_{2}$. In some experiments, the distal part of lumbar dorsal rootlet was placed into a suction electrode. By means of a Grass stimulator connected to the suction electrode through a stimulus-isolating unit, repetitive electrical pulses $(0.4 \mathrm{~ms}, 10 \mathrm{~Hz})$ were applied to recruit segmental afferent fibers.

Whole-cell patch-clamp recordings. Whole-cell patch-clamp recordings were made from motoneurons innervating the triceps surae muscle backlabeled with a fluorescein-conjugated cholera toxin (as described previously) or from unidentified motoneurons defined as large cells located in the lateral ventral horn. Whole-cell patch-clamp recordings in current-clamp mode were performed with a Multiclamp 700B amplifier (Molecular Devices). Patch electrodes (3-4 M $\Omega$ ) were pulled from borosilicate glass capillaries ( $1.5 \mathrm{~mm}$ outer diameter, $1.12 \mathrm{~mm}$ inner diameter; World Precision Instruments) on a Sutter P-97 puller (Sutter Instruments) and filled with intracellular solution containing the following (in $\mathrm{mm}): 140 \mathrm{~K}^{+}$-gluconate, $5 \mathrm{NaCl}, 2 \mathrm{MgCl}_{2}, 10 \mathrm{HEPES}, 0.5 \mathrm{EGTA}, 2 \mathrm{ATP}$, 0.4 GTP, pH 7.3 (280-290 mOsm). In some recordings, 10 mM BAPTA was added in the pipette solution to chelate intracellular free $\mathrm{Ca}^{2+}$. Pipette and neuronal capacitive currents were canceled, and after breakthrough, the series resistance was compensated and monitored. Recordings were digitized on-line and filtered at $10 \mathrm{kHz}$ (Digidata 1322A, Molecular Devices). Access resistance was monitored periodically throughout the experiments by a brief $10 \mathrm{mV}$ or $10 \mathrm{pA}$ hyperpolarizing step during voltage-clamp and current-clamp experiments, respectively.

Data analysis. Electrophysiological data were analyzed off-line with Clampfit 9 software (Molecular Devices). Only cells exhibiting a stable resting, holding membrane potential, access resistance (no $>20 \%$ varia- tion) and an action potential amplitude larger than $45 \mathrm{mV}$ were considered. The instantaneous frequency of firing was measured. To investigate the slow afterdepolarization (sADP), a train of spikes was evoked by a $2 \mathrm{~s}$ current pulse at holding potential. The peak amplitude of the sADP was measured from the holding potential $-60 \mathrm{mV}$. The sADP area was measured between the end of the stimulus pulse and the return of membrane voltage to control value. Only traces without spiking after the end of the depolarizing pulse were considered for such analysis. Traces with depolarizing current pulses of the same amplitude were chosen to compare the effect of drugs on sADP. If necessary, using bias currents, the prepulse membrane potential was maintained at the holding potential fixed in control condition. Data are presented as means \pm SEM. Nonparametric statistical analysis were used with a Wilcoxon matched pairs test when two groups were compared and a Kruskal-Wallis test followed by a Dunns post-test for multiple groups comparisons. Values of $p<0.05$ were considered significant (GraphPad Software).

Drug list. The following pharmacological agents from Sigma-Aldrich were used: apamin $(100 \mathrm{~nm})$, BAPTA $(10 \mathrm{~mm})$, bicuculline $(20 \mu \mathrm{M})$, cadmium chloride $(100 \mu \mathrm{M})$, capaszepine $(10 \mu \mathrm{M})$, carbenoxolone (50 $\mu \mathrm{M})$, flufenamic acid (FFA; $50 \mu \mathrm{M}$ ), gadolinium $\left(\mathrm{Gd}^{3+} ; 100 \mu \mathrm{M}\right)$; isopentenyl pyrophosphate (IPP; $200 \mu \mathrm{M})$; lanthanum $\left(\mathrm{La}^{3+} ; 100 \mu \mathrm{M}\right)$, mefloquine $(50 \mu \mathrm{M})$, nifedipine $(20 \mu \mathrm{M})$, nimodipine $(20 \mu \mathrm{M})$, riluzole $(5 \mu \mathrm{M})$, RN-1734 $(50 \mu \mathrm{M})$, strychnine $(1 \mu \mathrm{M})$, tetraethylammonium chloride (TEA; $10 \mathrm{~mm})$, tranilast $(150 \mu \mathrm{M})$, veratridine $(40 \mathrm{nM}), \omega$-agatoxin IVA $(200 \mathrm{nM}), \omega$-conotoxin-GVIA $(1 \mu \mathrm{M})$, and $4 \alpha$-Phorbol 12-13dicaprinate $(4 \alpha \mathrm{PDD} ; 50 \mu \mathrm{M})$. In addition, DL-2-amino-5-phosphonopentanoic acid (AP5; $50 \mu \mathrm{M}), 2$-aminoethoxydiphenyl borate $(50-200 \mu \mathrm{M})$, camphor (1-10 $\mu \mathrm{M})$, capsaicin (5-10 $\mu \mathrm{M})$, 6-cyano-7-nitroquinoxaline-2,3dion (CNQX; $10 \mu \mathrm{M})$, probenecid $(250 \mu \mathrm{M})$, SKF $96365(50 \mu \mathrm{M})$, and tetrodotoxin citrate (TTX; $20 \mathrm{~nm}-1 \mu \mathrm{M}$ ) were purchased from Tocris Bioscience). Nifedipine, nimodipine, tranilast, probenecid, $4 \alpha$-Phorbol 12-13-dicaprinate, and riluzole were dissolved in dimethylsulphoxide (DMSO) and added to the ACSF (final concentration of DMSO: 0.05$0.1 \%$ ). Vehicle had no effect on sADP or plateau potentials (data not shown). $\mathrm{Ca}^{2+}$-free solution was made by removing $\mathrm{Ca}^{2+}$ chloride from the recording solution and replacing it with an equimolar concentration of magnesium chloride. Low- $\mathrm{Na}^{+}$solution was made with substituting equimolar concentrations of $\mathrm{Na}^{+}$chloride by choline chloride.

\section{Results}

\section{Characterization of plateau potentials in ankle} extensor motoneurons

Data were collected from 35 motoneurons innervating the triceps surae muscles that were retrogradely labeled by a fluoresceinconjugated cholera toxin (Fig. 1A). The firing pattern of motoneurons recorded in normal ACSF was classified as either "bistable" (Fig. 1B1-B3) or "non-bistable" (Fig. 1C). Bistable motoneurons were characterized by a steep increase of the firing rate during the depolarizing pulse. From a holding potential of $\sim 10-15 \mathrm{mV}$ or less below spike threshold, bistable motoneurons displayed a self-sustained firing when the depolarizing pulse was increased in intensity (Fig. 1B1) or duration (Fig. 1B2). The bistability could never be elicited from the resting membrane potential but required a baseline depolarization to be triggered (Fig. 1B3). This long-lasting state of sustained spiking was reliable throughout the recording session and stable (tested up to $5 \mathrm{~min}$ ) until a hyperpolarizing current was injected. The intracellular dialysis in whole-cell recordings was not responsible for bistable behaviors as they were successfully recorded in the cell-attached configuration in three of four cells tested (data not shown). At hyperpolarized potentials, bistable motoneurons displayed a characteristic slow depolarizing afterpotential that outlasted the stimulus (Fig. 1B3, gray arrow) as previously observed in various CNS neurons (Hasuo et al., 1990; Friedman et al., 1992; Fraser and MacVicar, 1996). We refer to this potential as the sADP (Fig. $1 B 1-B 3$, arrows). Instead of a SADP, a pronounced afterhyperpo- 
A

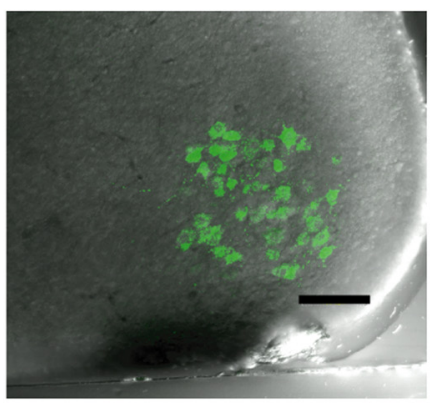

B2
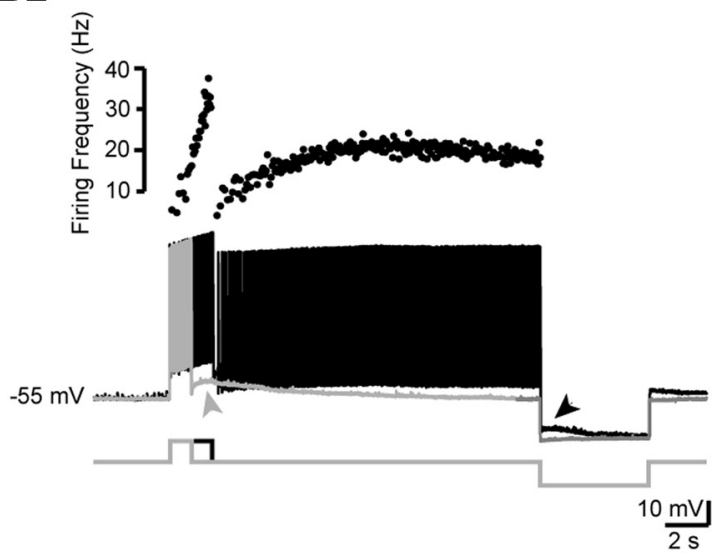

C

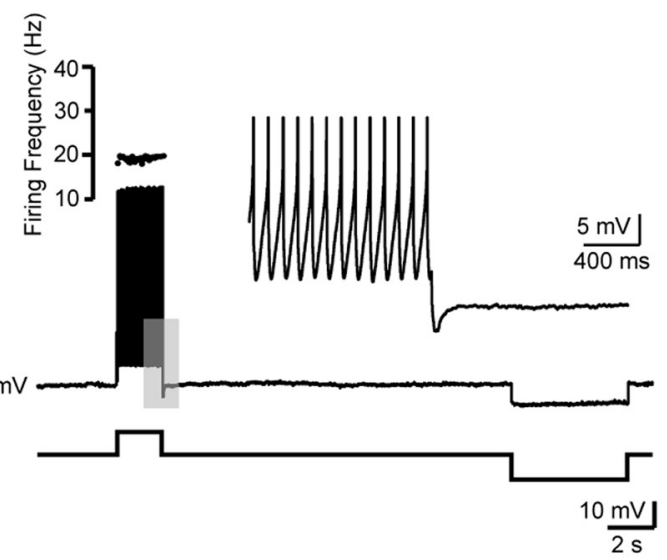

E

CNQX+AP5

Strychnine+Bicuculline

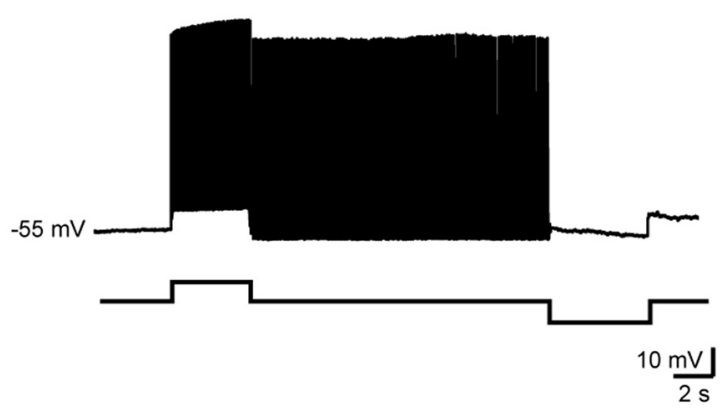

B1
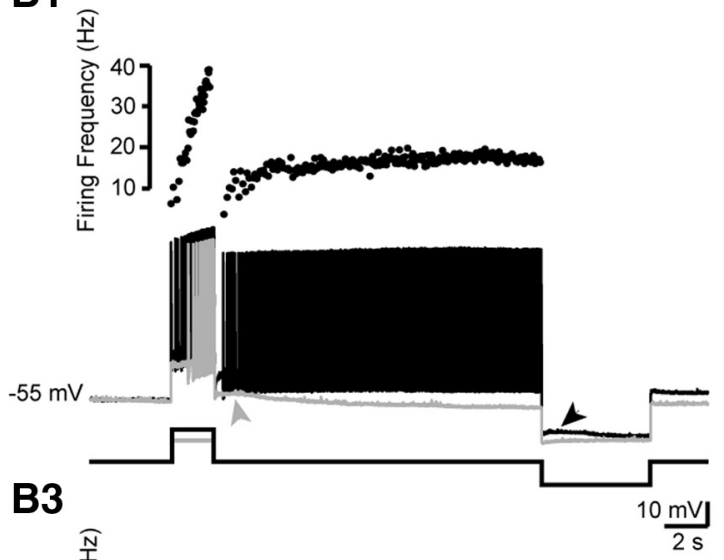

D
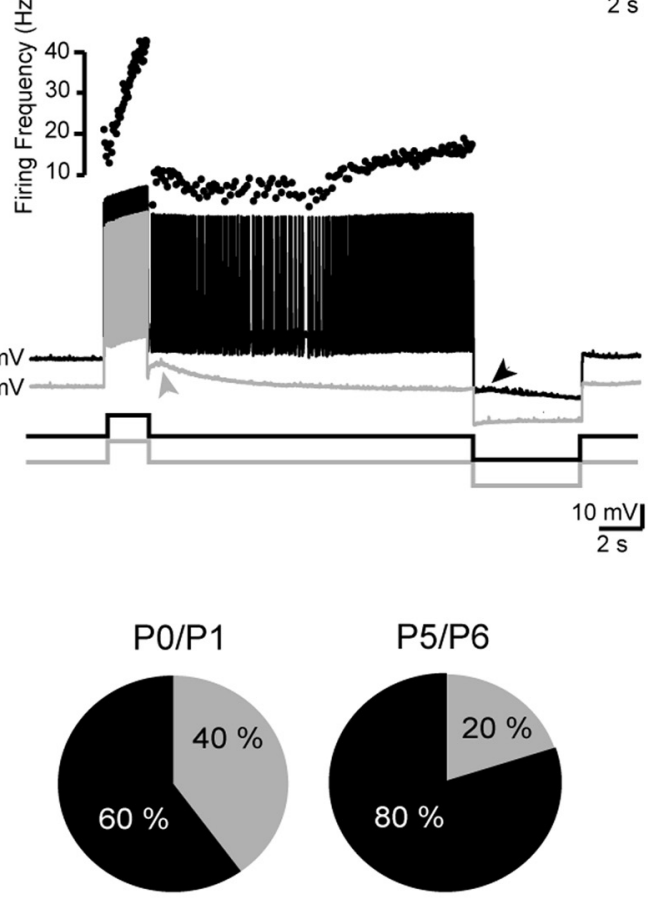

Bistable

Non-bistable

F

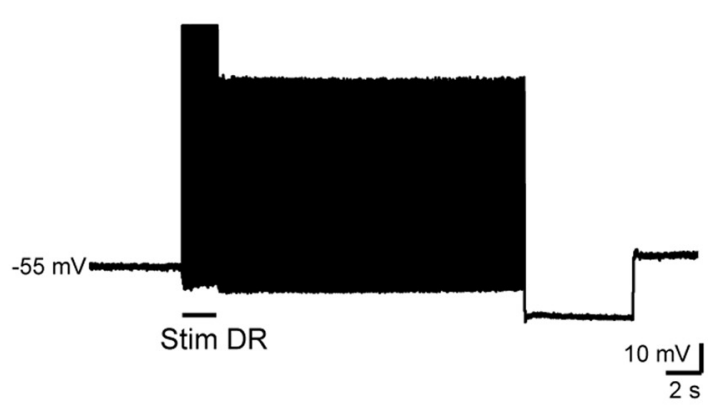

Figure 1. Electrophysiological properties of plateau potentials. $A$, Confocal image of a transverse section of the lumbar spinal cord shows motoneurons retrogradely labeled with the fluoresceinconjugated cholera toxin B subunit tracer injected into the triceps surae muscle. Scale bar, $100 \mu \mathrm{m}$. B, Bistable motoneuron displaying a plateau potential (black traces) when the depolarizing current pulse was increased either in amplitude (B1) or in duration (B2) or when the holding membrane potential was depolarized (B3). Current pulses in $\mathbf{B} 2$ and $\mathbf{B} 3$ were given from a depolarized membrane potential using bias current. Gray traces show the SADP outlasting the current pulse when the voltage threshold to trigger the plateau potential was not reached. (Figure legend continues.) 
larization and the absence of an accelerating discharge during the pulse characterized non-bistable motoneurons (Fig. 1C).

Bistable motoneurons increased in proportion during the first postnatal week from $\sim 60 \%(12 / 20)$ at P0/P1 to $80 \%(12 / 15)$ at P6/P7 (Fig. 1D). Such bistable properties were not caused by local reverberating circuit, because they were observed also when glutamatergic-, GABA-, and glycine-mediated transmissions were blocked (Fig. 1E). However, similar self sustained firing could be induced by dorsal root stimulation in the absence of any pharmacological blockade (Fig. $1 F$ ).

\section{The sADPs and plateau potentials are closely related}

From this part of the study, 263 recordings were performed in presumed motoneurons targeted as the largest cells in the lateral part of the fourth/fifth lumbar ventral horn (where triceps surae's motoneurons are located; Fig. 1A), during the second half of the first postnatal week (P4/P6). Because the proportion (74\%) and the ionic basis of their bistable properties are similar to those of the triceps surae's motoneurons, they have been pooled altogether. In bistable motoneurons, increasing the pulse intensity $(n=8$; Fig. $2 A 1)$ or duration ( $n=8$; Fig. $2 A 2)$ always enhanced the sADP which could ultimately give rise to a transient spiking activity. The area of the sADP was strongly correlated with the number of spikes evoked during the stimulus (Fig 2A1,A2, insets). To test the impact of the sADP on the generation of plateau potentials a rheobasic current pulse was injected repeatedly. A summation of sADP (windup) was observed and the current pulse, which initially triggered a single spike, then evoked repetitive firing ( $n=9$; Fig. 2B1). Similar results were obtained when the trials were performed at more depolarized values but the windup led to a plateau potential (Fig. 2B2). To further identify the causal relationship between the two phenomena, a sequence of brief suprathreshold depolarizing pulses was delivered after the initial $2 \mathrm{~s}$ square depolarizing pulse $(n=15 ; \mathrm{Fig}$. $2 C)$. With this protocol, the initial sADP (Fig. $2 C$, gray trace) was maintained and initiated a plateau potential (Fig. $2 C$, black trace). These data indicate that the plateau potential relies on a cumulative depolarization generated by the SADP.

\section{Self-sustained firing, but neither the sADP nor the plateau potential, relies on persistent inward currents}

Considering the critical role of the L-type $\mathrm{Ca}^{2+}$ channels in generating plateau potentials in many preparations (Hounsgaard and Mintz, 1988; Hounsgaard and Kiehn, 1993; Heckman et al., 2003; Li and Bennett, 2003; Carlin et al., 2009), we tested their contribution to self-sustained firing in neonatal motoneurons. The application of nifedipine $(20 \mu \mathrm{M})$ or nimodipine $(20 \mu \mathrm{M})$, two specific L-type $\mathrm{Ca}^{2+}$ channel blockers, reversibly abolished bistable behaviors in approximately half of bistable motoneurons (3/7 cells; Fig. $3 A 1, A 2)$ and did not affect them on the others (4/7 cells; Fig. 3A3). The contribution of the $\mathrm{Na}^{+}$persistent inward

(Figure legend continued.) C, Firing properties of a non-bistable motoneuron unable to generate a plateau potential in response to a 2 s depolarizing current pulse. C, Inset, Illustrates with expanded time scale the typical pronounced afterhyperpolarization (AHP) that follows the current pulse (action potentials are truncated). $\boldsymbol{B}, \boldsymbol{C}$, Instantaneous frequency plots are shown on top of intracellular recordings. $\boldsymbol{D}$, Proportions of bistable and non-bistable motoneurons at the beginning and the end of the first postnatal week. $\boldsymbol{E}$, Plateau potential triggered by a brief depolarizing current pulse in the presence of $\mathrm{CNQX}(10 \mu \mathrm{M}), \mathrm{AP} 5(50 \mu \mathrm{M})$, strychnine $(5 \mu \mathrm{M})$ and bicuculline $(20 \mu \mathrm{m})$. $\boldsymbol{F}$, Electrical stimulation of the dorsal root $(10 \mathrm{~Hz}, 2 \mathrm{~s})$ induced plateau potential, which was stopped by hyperpolarization. In this and the following figures, bottom traces are the injected current. current (Tazerart et al., 2007) was then investigated. The blockade of persistent sodium current $\left(\mathrm{I}_{\mathrm{NaP}}\right)$ by riluzole $(5 \mu \mathrm{M})$ gradually decreased self-sustained firing in duration until it was reversible suppressed in all motoneurons tested ( $n=11$ cells; Fig. $3 B 1)$. The involvement of $\mathrm{I}_{\mathrm{NaP}}$ was confirmed by low concentration of TTX (20 nM) that did not affect spikes ( $n=10$ cells; Fig. $3 B 2)$. By contrast, the alkaloid veratridine, by upregulating $\mathrm{I}_{\mathrm{NaP}}$ in spinal neurons (Tazerart et al., 2008), facilitated the emergence of self-sustained firing $(n=5$; Fig. $3 C)$. The addition of TTX specifically blocked the veratridine-induced bistable properties without affecting evoked action potentials (data not shown). Although $\mathrm{I}_{\mathrm{NaP}}$ and to a lesser extent L-type $\mathrm{Ca}^{2+}$ currents appear to be important for self-sustained firing, they are not responsible for plateau potentials as the SADP persisted in the presence of L-type $\mathrm{I}_{\mathrm{Ca}}$ or $\mathrm{I}_{\mathrm{NaP}}$ blockers (Fig. $3 A, B$ ).

\section{The ionic nature of the sADP}

\section{The $\mathrm{Ca}^{2+}$ spike is a prerequisite for the SADP to occur}

To check whether action potentials are necessary for the sADP, we used TTX at a concentration $(1 \mu \mathrm{M})$ that blocks both $\mathrm{Na}^{+}$ spikes and $\mathrm{I}_{\mathrm{NaP}}$. The amplitude of the sADP was decreased as action potentials were suppressed $(7.8 \pm 0.7 \mathrm{mV}$ vs $2.5 \pm 0.3 ; p<$ 0.001 , Wilcoxon paired test, $n=11$ cells; Fig. $4 A$ ). However, the sADP was resurrected when a current command mimicking action potentials was added to the $2 \mathrm{~s}$ depolarizing pulse (Fig. $4 B$ ). These data eliminate the involvement of TTX-sensitive voltageactivated $\mathrm{Na}^{+}$channels in the sADP and suggest the essential role of TTX-resistant high voltage-activated channels in generating the sADP. In line with this hypothesis, the superfusion of TEA (10 $\mathrm{mM}$ ), a potassium channel blocker, simultaneously unmasked TTX-resistant spikes and the sADP (Fig. 4C). The removal of $\mathrm{Ca}^{2+}$ from the external solution suppressed spikes and virtually abolished the sADP $(13.9 \pm 1.4 \mathrm{mV}$ vs $4.2 \pm 0.6 \mathrm{mV}$; $p<0.01$, Wilcoxon paired test, $n=8$ cells; Fig. $4 D$ ). These results indicate that the sADP relies on $\mathrm{Ca}^{2+}$-dependent mechanisms.

Involvement of high-voltage-dependent $\mathrm{Ca}^{2+}$ channels

To determine whether voltage-gated $\mathrm{Ca}^{2+}$ channels were required for the sADP, a broad-spectrum $\mathrm{Ca}^{2+}$ channel blocker, cadmium $(100 \mu \mathrm{M})$, was perfused. In the presence of TTX, the sADP unmasked by TEA was depressed by cadmium $(15.8 \pm 2.2$ $\mathrm{mV}$ vs $5.5 \pm 0.8 \mathrm{mV} ; p<0.01$, Wilcoxon paired test, $n=9$ cells; Fig. $5 A$ ). These results suggest that $\mathrm{Ca}^{2+}$ influx associated with spiking is important in generating the sADP. Because spiking is expected to cause $\mathrm{Ca}^{2+}$ influx through high-voltage-activated $\mathrm{Ca}^{2+}$ channels, we determined which channel subtype was involved. Bath application of nifedipine $(20 \mu \mathrm{M})$ produced a decrease of the sADP $(12.7 \pm 1.9 \mathrm{mV}$ vs $5.7 \pm 1 \mathrm{mV} ; p<0.01$, Kruskal-Wallis test, $n=8$ cells; Fig. $5 B$, light gray trace) associated with the abolition of spikes. Notably, both sADP and spikes reappeared when the motoneuron was strongly depolarized $(5.7 \pm 1 \mathrm{mV}$ vs $13.1 \pm 2.1 \mathrm{mV} ; p<0.01$, Kruskal-Wallis test, $n=$ 8 cells; Fig. $5 B$, dark gray trace). This result raised the possibility that more than one type of $\mathrm{Ca}^{2+}$ channel was involved. Application of $\omega$-conotoxin-GVIA ( $1 \mu \mathrm{M}$; Fig. $5 C)$, an N-type channel blocker, or $\omega$-agatoxin IVA (200 nм; Fig. 5D), a P/Q-type channel blocker, substantially decreased the peak amplitude of $\mathrm{Ca}^{2+}$ spikes without significant effect on the sADP $(12 \pm 1.5 \mathrm{mV}$ vs $11.7 \pm 1.7 \mathrm{mV}$ and $16 \pm 1.1 \mathrm{mV}$ vs $15 \pm 2.3 \mathrm{mV}$, respectively; $p>$ 0.05 , Wilcoxon paired test, $n=6$ and $n=3$ cells, respectively; Figs. $5 C, D)$. Together, these data suggest that high-voltageactivated $\mathrm{Ca}^{2+}$ channels, particularly the L-type ones, take part in generating the sADP. 
Plateau potentials depend on a $\mathrm{Ca}^{2+}$ activated current that uses $\mathrm{Na}^{+}$as the main charge carrier

The $\mathrm{Ca}^{2+}$ dependence of the sADP may reflect two mechanisms: (1) $\mathrm{Ca}^{2+}$ acts as the main charge carrier or, alternatively, (2) the $\mathrm{Ca}^{2+}$ influx acts upstream and triggers a $\mathrm{Ca}^{2+}$-activated current. To identify which of these two mechanisms is involved, we chelated intracellular $\mathrm{Ca}^{2+}$ by adding BAPTA $(10 \mathrm{~mm})$ to the internal solution. The sADP gradually decreased as the neuron was progressively loaded with BAPTA, and completely disappeared after $\sim 5$ min of whole-cell recording $(11 \pm 1 \mathrm{mV}$ vs $-1.8 \pm 0.8 \mathrm{mV} ; p<0.01$, Wilcoxon paired test, $n=8$ cells; Fig. $6 A$ ). This abolition was not due to a nonspecific inhibition of $\mathrm{Ca}^{2+}$ influx because $\mathrm{Ca}^{2+}$ spikes were still observed. Thus, although the $\mathrm{Ca}^{2+}$ influx through voltageactivated $\mathrm{Ca}^{2+}$ channels is a prerequisite for the sADP, it does not underlie the sADP itself. The $\mathrm{Ca}^{2+}$ appeared to activate a conductance responsible for the sADP that uses another ion as the main charge carrier. To characterize the current mediating the sADP we investigated its reversal potential. The current-voltage relationship of the sADP was examined at various holding potentials under voltageclamp (Fig. 6B). The tail current underlying the sADP was evoked from the holding potential of $-60 \mathrm{mV}$ by a $2 \mathrm{~s}$ depolarizing pulse that returned to different membrane potentials. To prevent interaction between the $\mathrm{Ca}^{2+}$-dependent potassium channels $\left(\mathrm{IK}_{\mathrm{Ca}}\right)$ and a putative $\mathrm{Ca}^{2+}$-activated nonselective cationic current $\left(\mathrm{I}_{\mathrm{CaN}}\right), \mathrm{K}_{\mathrm{Ca}}$ channels were blocked by apamin (100 nM). The protocol induced an inward current that displayed a time course similar to the depolarization observed in current-clamp mode (Fig. 6B, left). The $I-V$ relationship was linear between -60 and $-20 \mathrm{mV}$ (Fig. $6 B$, right, black trace). With the caution of the likely incomplete space clamp of dendrites (Carlin et al., 2009) the reversal potential extrapolated from the $I-V$ curve has been estimated between +20 and $+30 \mathrm{mV}$ ( $n=5$ cells). Such a value suggests that the current is carried by a mixture of cations. The role of $\mathrm{Na}^{+}$was tested by replacing most of the external $\mathrm{Na}^{+}$with equimolar amount of choline. Reducing the extracellular $\mathrm{Na}^{+}$from 152 to $26 \mathrm{~mm}$ clearly depressed the inward current (for a holding potential set at $-60 \mathrm{mV}: 373.4 \pm 39.7 \mathrm{pA}$ vs $74.8 \pm 26.8 \mathrm{pA} ; p<0.05$, Wilcoxon paired test, $n=7$ cells; Fig. $6 C$ ) and made the $I-V$ curve flat (Fig. $6 B$, right, gray trace). Recorded in current-clamp, the sADP in low $\mathrm{Na}^{+}$was reversibly decreased $(11.9 \pm 2.2 \mathrm{mV}$ vs $1.9 \pm 0.3 \mathrm{mV} ; p<0.01$, Wilcoxon

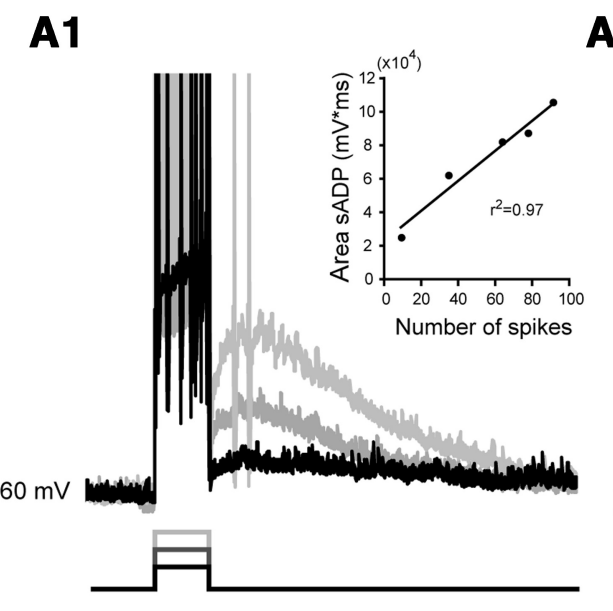

A2
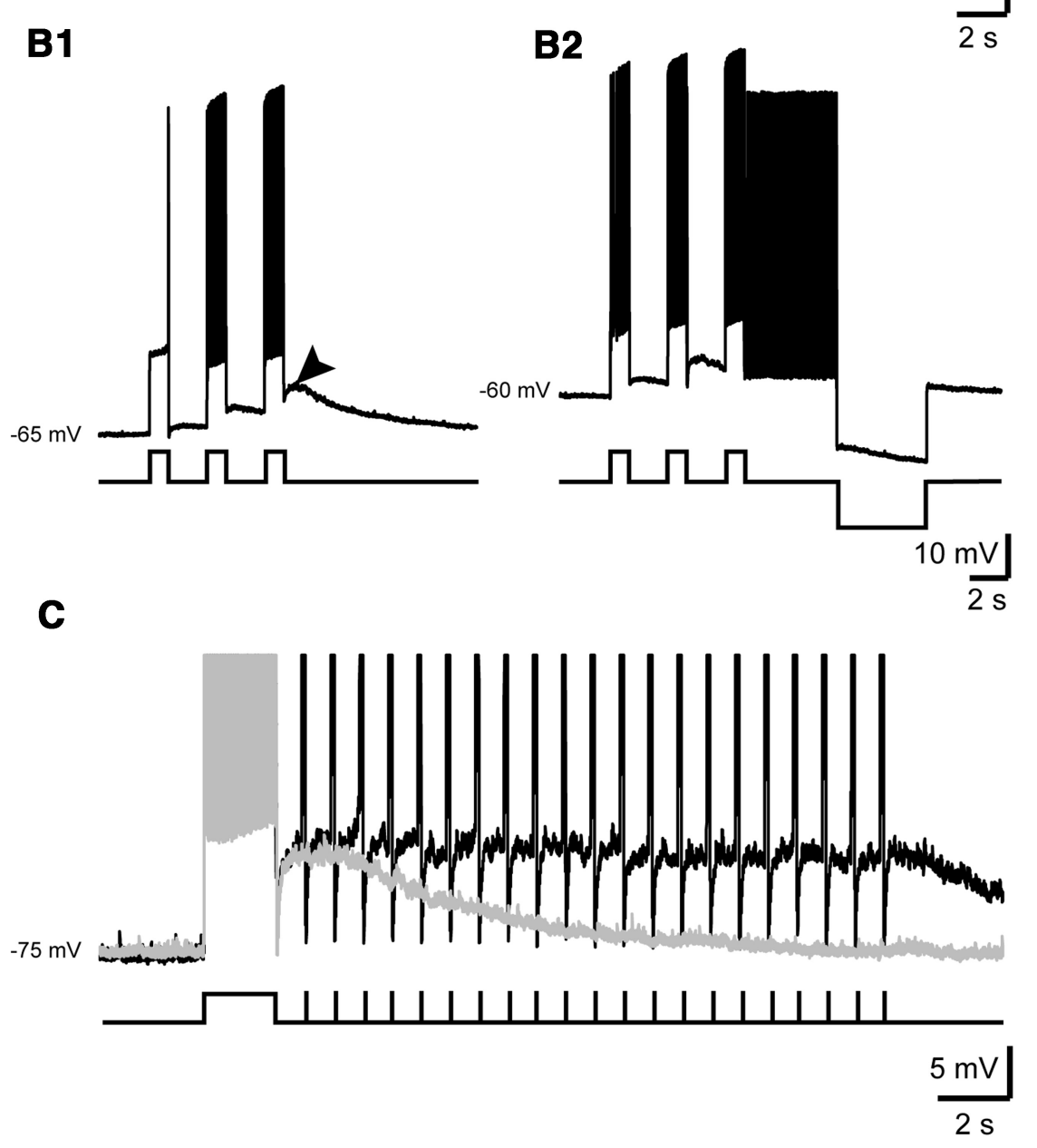

Figure 2. Electrophysiological properties of the SADP. A, Superimposed voltage traces from a motoneuron showing the sADP in response to current steps of increasing amplitude $(\boldsymbol{A} \mathbf{1})$ or duration $(\boldsymbol{A 2})$. $\boldsymbol{A}$, Insets, The linear relationship between the area of the SADP and the number of spikes during the stimulus. $\boldsymbol{B}$, Voltage traces illustrating the wind-up of the SADP in response to repetitive depolarizing current pulses of constant amplitude applied either at resting membrane potential (B1) or at a more depolarized potential producing a plateau potential (B2). C, Superimposed voltage traces from a bistable motoneuron recorded at resting membrane potential illustrating the switch of the SADP (gray trace) into a plateau potential (black trace) when the initial 2 s square pulse was followed by a sequence of suprathreshold depolarizing current pulses. paired test, $n=8$ cells; Fig. $6 D$ ). In agreement with the involvement of the sADP in bistable behaviors, the plateau potential evoked by a sequence of depolarizing current pulses was abolished in low- $\mathrm{Na}^{+}$solution (Fig. 6E). We conclude that the sADP 
A1

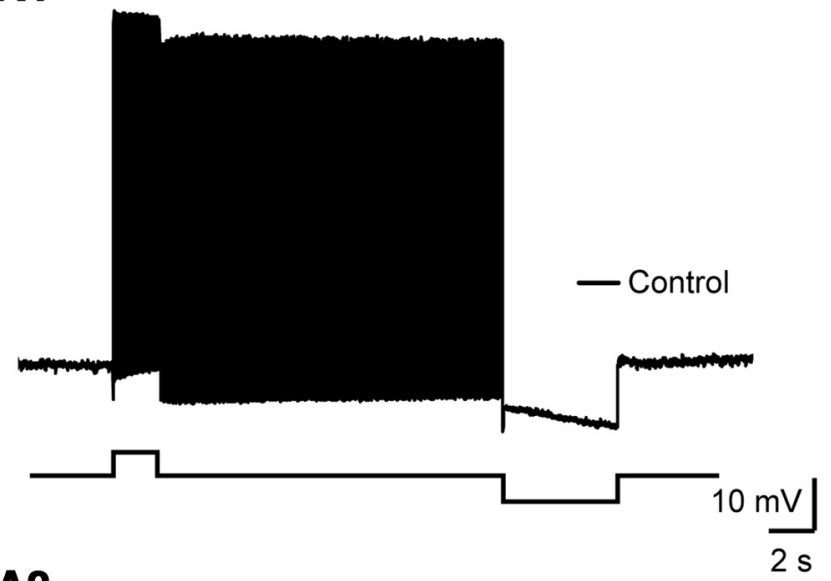

A2
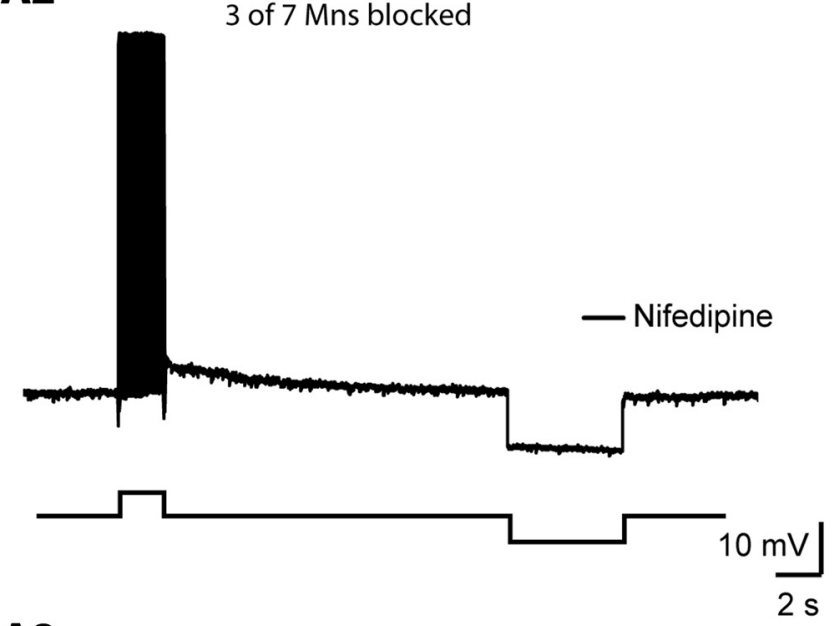

A3

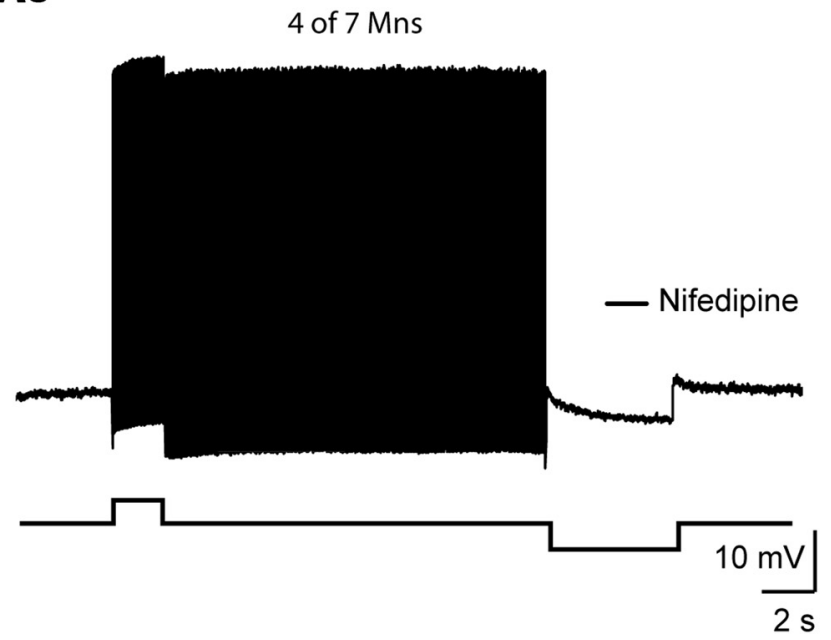

B1

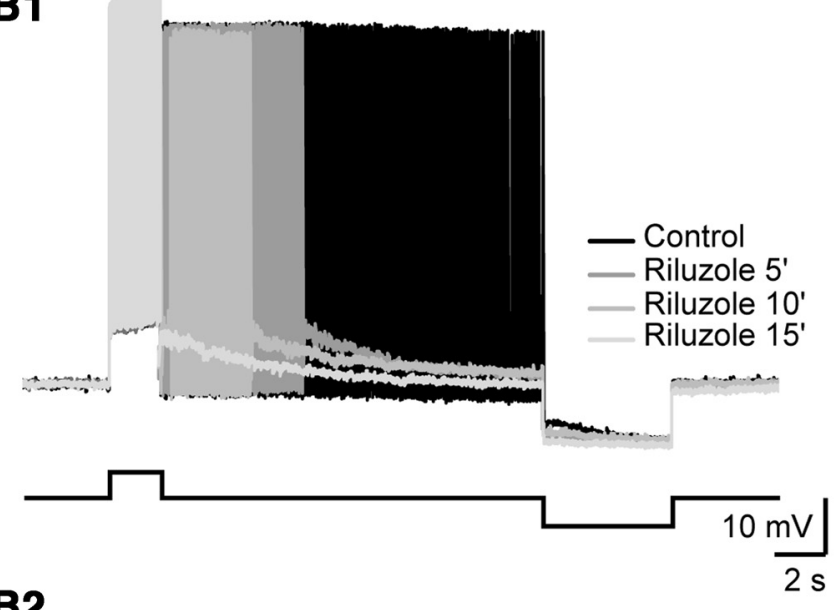

B2

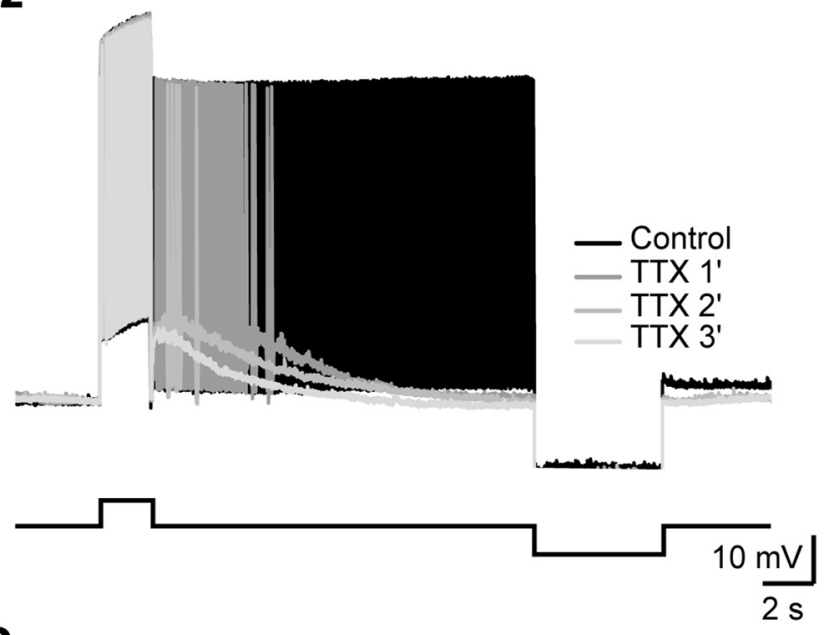

C

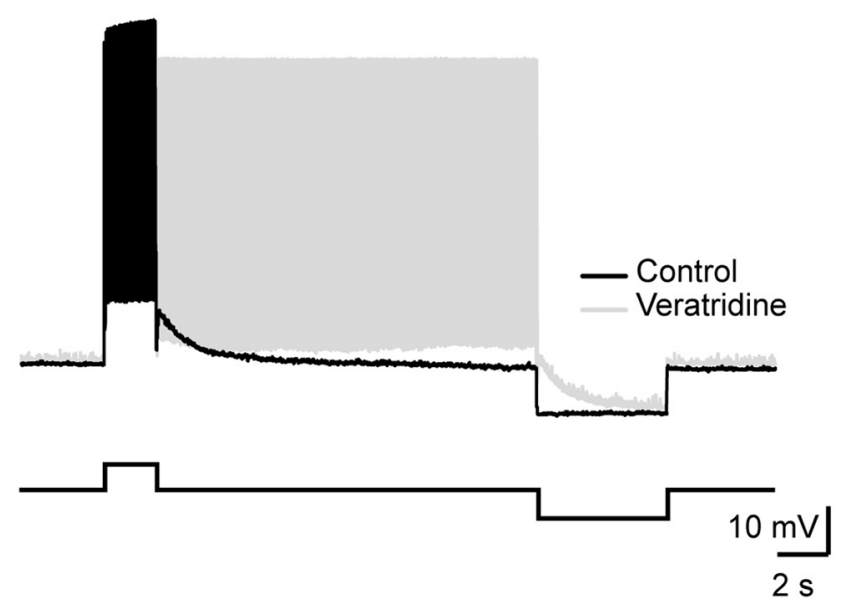

Figure 3. Pharmacological profile of plateau potentials. $\boldsymbol{A} 1-\mathbf{A}$ : Effect of blocking the L-type $\mathrm{Ca}^{2+}$ channels by nifedipine $(20 \mu \mathrm{M})$ on plateau potentials. $\boldsymbol{B}$, Effect of the progressive blockade of the persistent sodium current by $5 \mu \mathrm{m}$ riluzole (B1) or $10 \mathrm{~nm}$ TTX (B2) on plateau potentials. C, Facilitation of plateau potentials by upregulating the persistent sodium current with veratridine ( 40 nM). Motoneurons (Mns) were recorded at a holding potential between -60 and $-55 \mathrm{mV}$.

and the related plateau potential were triggered in lumbar motoneurons by a $\mathrm{Ca}^{2+}$-dependent mechanism activating a $\mathrm{Na}^{+}$ inward current. This is consistent with the properties of an $\mathrm{I}_{\mathrm{CaN}}$. The $\mathrm{Na}^{+} / \mathrm{Ca}^{2+}$ exchanger is not responsible for the sADP

Aside from a contribution of $\mathrm{I}_{\mathrm{CaN}}$, we had to consider the $\mathrm{Na}^{+}$/ $\mathrm{Ca}^{2+}$ exchanger as a putative mechanism underlying the sADP (Friedman et al., 1992). Such exchanger evokes a depolarizing current by intruding three $\mathrm{Na}^{+}$ions in exchange of one $\mathrm{Ca}^{2+}$ ion. The involvement of a Na${ }^{+} / \mathrm{Ca}^{2+}$ exchanger was tested in two ways. First, we replaced extracellular $\mathrm{Na}^{+}$with equimolar $\mathrm{Li}^{+}$ that inhibits the $\mathrm{Na}^{+} / \mathrm{Ca}^{2+}$ exchanger (Reuter and Porzig, 1995) but permeates $\mathrm{Ca}^{2+}$-activated nonselective cation channels (Yellen, 1982). This condition did not affect the amplitude of the $\operatorname{sADP}(11.8 \pm 1.8 \mathrm{mV}$ vs $11.6 \pm 1.3 \mathrm{mV} ; p>0.05$, Wilcoxon 
paired test, $n=6$ cells; Fig. $6 F$ ). In an additional series of experiments, we used the isothiourea derivative KB-R7943 (50 $\mu \mathrm{M})$, which selectively inhibits the $\mathrm{Na}^{+}$/ $\mathrm{Ca}^{2+}$ exchanger. This blocker did not alter the sADP $(7 \pm 2.4 \mathrm{mV}$ vs $7 \pm 2.4 \mathrm{mV}$; $p>0.05$, Wilcoxon paired test, $n=4$ cells; data not shown). These findings imply that the $\mathrm{Na}^{+} / \mathrm{Ca}^{2+}$ exchanger plays a minor role, if any, in the genesis of the sADP.

\section{TRPV cation channels upregulate}

the $S A D P$

The involvement of $\mathrm{I}_{\mathrm{CaN}}$ in the sADP was investigated further using either flufenamate (50 $\mu \mathrm{M} ; n=9$ cells; Fig. $7 A$ ), ruthenium red $(10 \mu \mathrm{M}$; data not shown; $n=$ 4 cells), or trivalent cations, such as $\mathrm{La}^{3+}$ $(100 \mu \mathrm{M} ; n=3$ cells; Fig. $7 B)$ or $\mathrm{Gd}^{3+}(100$ $\mu \mathrm{M}$, data not shown; $n=2$ cells), routinely used to block $\mathrm{I}_{\mathrm{CaN}}$ (Table 1). Whatever the blocker used, $\mathrm{Ca}^{2+}$ spikes were abolished and the SADP was significantly lowered $(13.1 \pm 1.6 \mathrm{mV}$ vs $2.9 \pm 0.4 \mathrm{mV}$; $p<0.001$, Wilcoxon paired test, $n=18$ cells; Fig. $7 A, B)$. The blockade of $\mathrm{Ca}^{2+}$ spikes emphasizes the side effects of such blockers on voltage-gated $\mathrm{Ca}^{2+}$ channels (Reichling and MacDermott, 1991; Guinamard et al., 2013). Channels responsible for $\mathrm{I}_{\mathrm{CaN}}$ are sorted into six subfamilies (for review, see Montell, 2005). To date, only TRPM (melestatin), TRPC (canonical), and TRPV channels are expressed in the CNS (Moran et al., 2004). A blocker of some TRPC channels (SKF 96365, $50 \mu \mathrm{M}$; Table 1$)$, did not affect the $\operatorname{sADP}(p>$ 0.05 , Wilcoxon paired test, $n=4$ cells; Fig. $7 C)$. Another compound, 2-APB (50 $\mu \mathrm{M})$, was used to block at least partially TRPC and TRPM channels (Table 1). Instead of a shortening, 2-APB caused a significant increase of both the amplitude $(11.7 \pm 1.7$ $\mathrm{mV}$ vs $18.1 \pm 1.4 \mathrm{mV} ; p<0.001$, Wilcoxon paired test, $n=11$ cells; Fig. $7 D)$ and the duration of the SADP (from $9.8 \pm$ $1.6 \mathrm{~s}$ to $19.2 \pm 0.4 \mathrm{~s} ; p<0.01$, Wilcoxon paired test, $n=11$ cells; Fig. $7 D$ ). Aside from its broad spectrum inhibition of TRPC and TRPM channels, 2-APB was recently identified as a chemical activator of TRPV1, TRPV2, and TRPV3 channels (Table 1).

Activation of TRPV2 channels upregulates the $s A D P$

We further tried to identify which of the TRPV channels was involved in the upregulation of the sADP. Capsaicin $(10 \mu \mathrm{M}$; Fig. $8 A 1)$ and capsazepine $(10 \mu \mathrm{M}$; Fig. $8 A 2$ ), a potent activator and a blocker of TRPV1 channels (Table 1), respectively, did not affect the sADP (for capsaicin: $7.7 \pm 2.6 \mathrm{mV}$ vs $7.6 \pm 2.6 \mathrm{mV}, n=4$ cells;
A
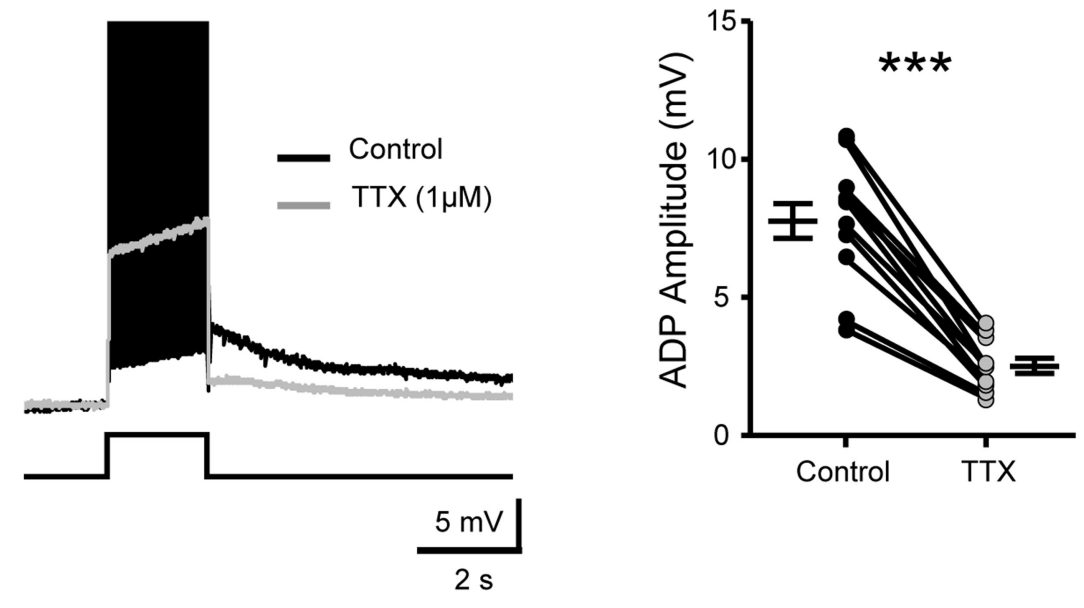

B

$$
\operatorname{TTX}(1 \mu \mathrm{M})
$$

C

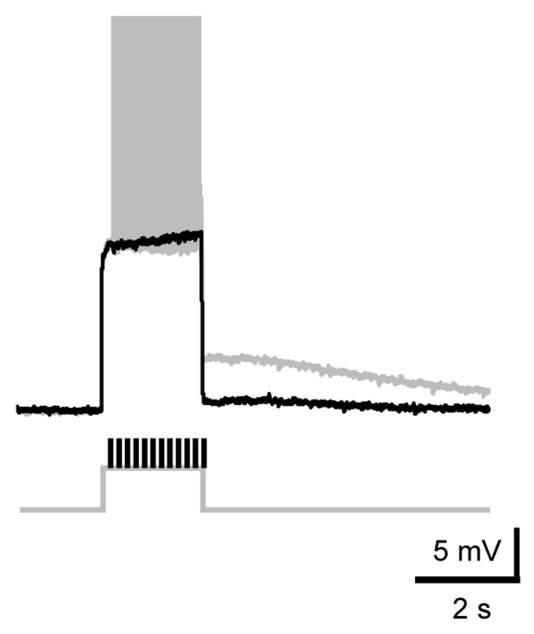

$\operatorname{TTX}(1 \mu \mathrm{M})$
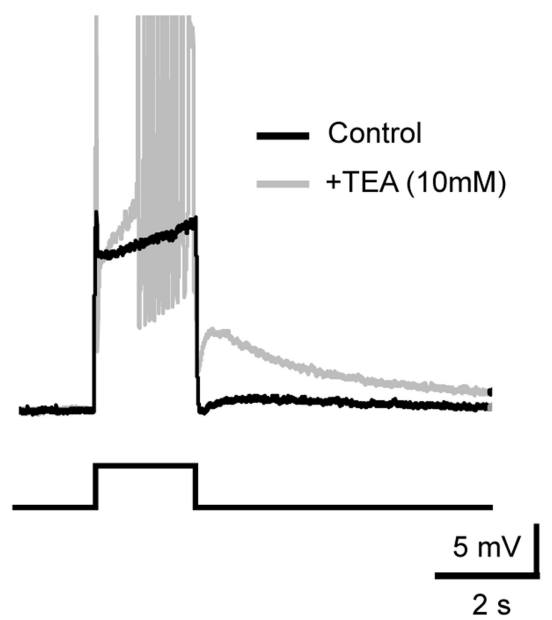

D
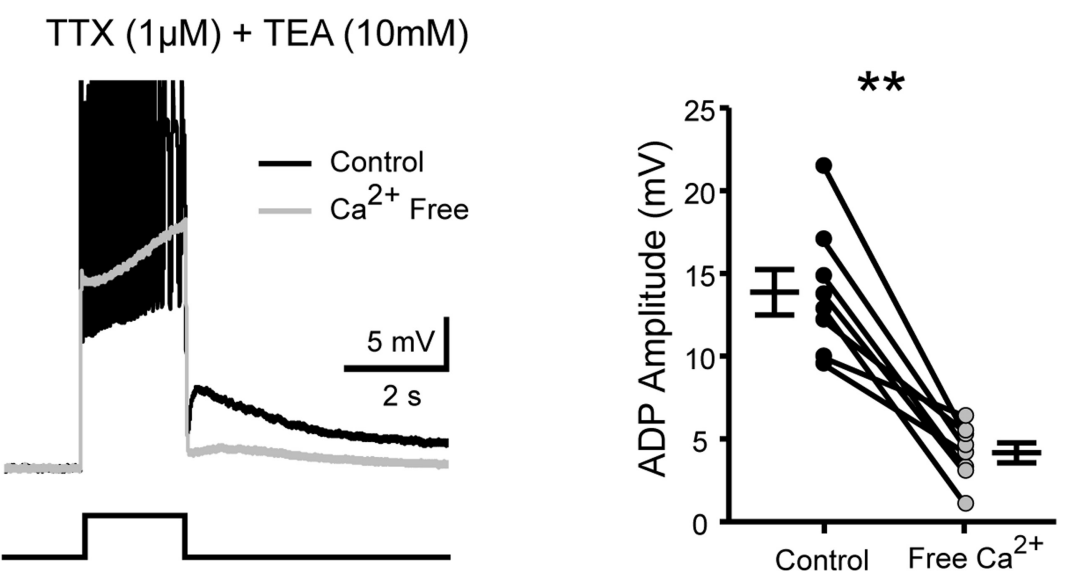

Figure 4. The SADP requires spiking-dependent $\mathrm{Ca}^{2+}$ influx. $\boldsymbol{A}$, Superimposed voltage traces in response to a $2 \mathrm{~s}$ depolarizing pulse before (black trace) and after (gray trace) TTX application (1 $\mu \mathrm{m})$. The graph shows the mean amplitude of the SADP before and after drug application. $\boldsymbol{B}$, Superimposed voltage traces collected under TTX, in response to $\mathrm{a} 2 \mathrm{~s}$ depolarizing pulse on which additional brief depolarizing pulses that mimic action potentials were (black trace) or were not (gray trace) applied. C, Superimposed voltage traces in response to a $2 \mathrm{~s}$ depolarizing pulse, collected under TTX before and after adding TEA (10 mM). D, Superimposed voltage traces in response to a $2 \mathrm{~s}$ depolarizing pulse, collected under TTX and TEA before and after the removal of extracellular $\mathrm{Ca}^{2+}$. Graphs show the mean amplitude of the sADP before and after removing $\mathrm{Ca}^{2+}$. Note that action potentials were truncated for the visualization of the sADP. Holding potential, $-60 \mathrm{mV}$. Error bars indicate SEM. ns, Not significant; ${ }^{* *} p<0.01,{ }^{* * *} p<0.001$ (Wilcoxon paired test). 
A

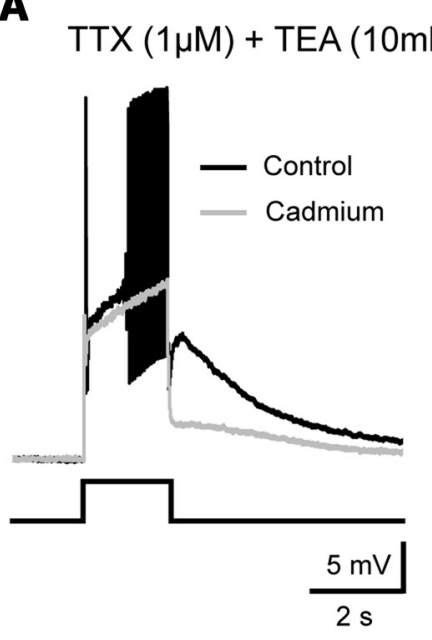

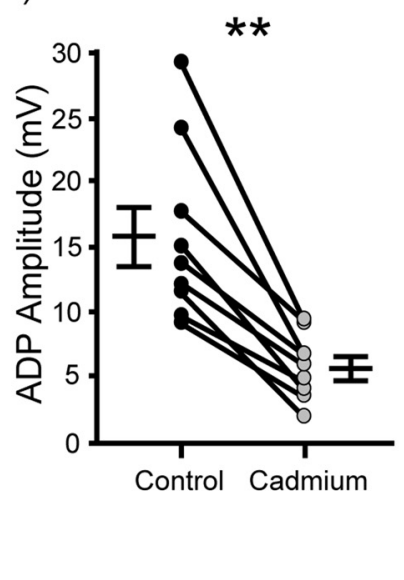

C
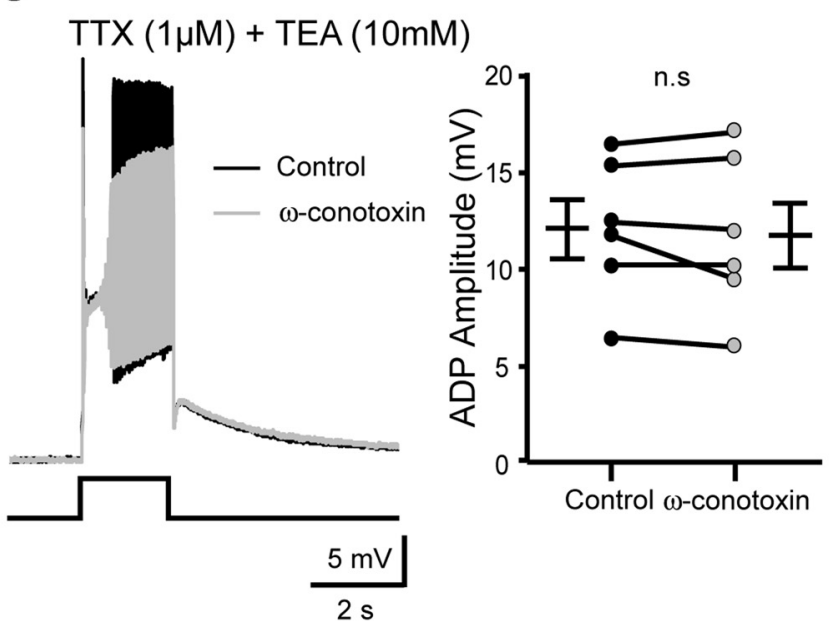

B

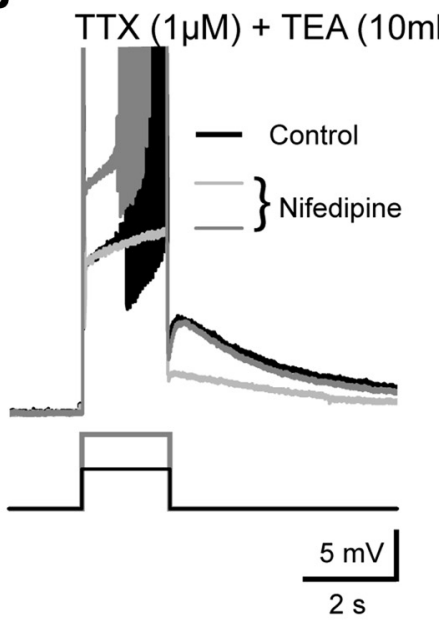

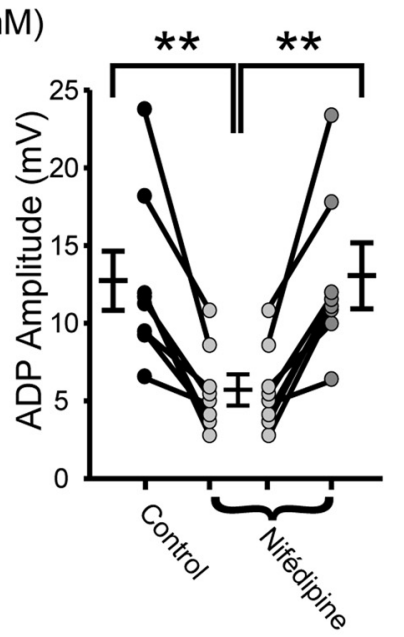

D

$\operatorname{TTX}(1 \mu \mathrm{M})+\operatorname{TEA}(10 \mathrm{mM})$

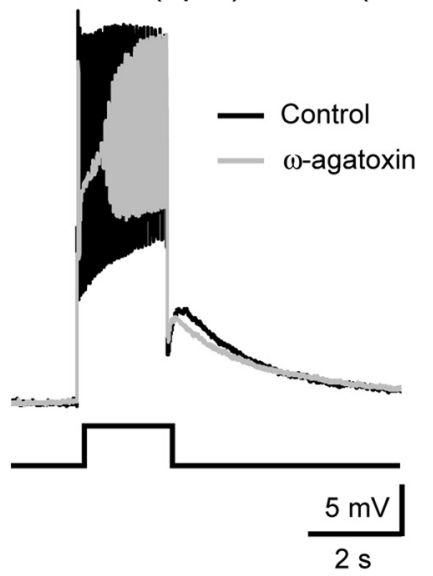

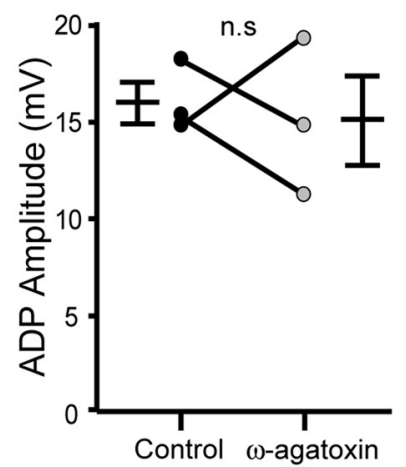

Figure 5. The L-type voltage-gated $\mathrm{Ca}^{2+}$ channels are primarily responsible for the spiking-dependent $\mathrm{Ca}^{2+}$ influx necessary to generate the sADP. $A-D$, Left, Superimposed voltage traces in response to a $2 \mathrm{~s}$ depolarizing pulse before (black traces) and after (gray traces) the addition of: (A) cadmium, a broad spectrum voltage-gated $\mathrm{Ca}^{2+}$ channels blocker (200 $\left.\mu \mathrm{M}\right),(\boldsymbol{B})$ nifedipine a L-type $\mathrm{Ca}^{2+}$ channels blocker $(20 \mu \mathrm{m}),(\boldsymbol{C}) \omega$-conotoxin GVIA $(1 \mu \mathrm{M})$ a N-type $\mathrm{Ca}^{2+}$ channels blocker, and (D) $\omega$-agatoxin VIA (200 nM) a P/Q-type Ca ${ }^{2+}$ channels blocker. Note that in the presence of nifedipine large depolarizing current pulses allow the recovery of both action potentials and SADP (dark gray trace). Right, Graphs show the mean amplitude of the sADP before and after the drug application. All recordings were made under TTX (1 $\mu \mathrm{M})$ and TEA (10 mM). Holding potential, $-60 \mathrm{mV}$. Error bars indicate SEM. ns, Not significant; ${ }^{*} p<0.05$, ${ }^{* *} p<0.01$ (Wilcoxon paired test in $\boldsymbol{A}, \boldsymbol{C}$, and $\boldsymbol{D}$ and Kruskal-Wallis test in $\boldsymbol{B})$.

for capsazepine: $10.6 \pm 0.8 \mathrm{mV}$ vs $10.6 \pm 0,9 \mathrm{mV}, n=4$ cells; $p>$ 0.05 , Wilcoxon paired test). These results corroborate anatomical evidence that motoneurons do not express TRPV1 channels (Mandadi et al., 2009). In contrast to TRPV1, TRPV2 and TRPV3 channels are expressed in lumbar motoneurons (Lewinter et al., 2004; Facer et al., 2007). The specific recruitment of TRPV2 channels by probenecid ( $250 \mu \mathrm{M}$; Table 1$)$ had a pronounced effect and, similar to 2-APB, increased the sADP amplitude $(13.7 \pm 2.5 \mathrm{mV}$ vs $17.1 \pm 2.6 \mathrm{mV} ; p<0.01$, Wilcoxon paired test, $n=8$ cells; Fig. 8 B1) and duration (from $9.3 \pm 1.6$ s to $18.9 \pm$ $0.8 \mathrm{~s} ; p<0.01$, Wilcoxon paired test, $n=8$ cells). In voltageclamp recordings, inward currents sustaining the SADP were significantly increased (for holding potential at $-60 \mathrm{mV}: 253 \pm 28$ pA vs $373 \pm 40 \mathrm{pA} ; p<0.01$, Wilcoxon paired test, $n=6$ cells; Fig. 8B2). Surprisingly, tranilast $(150 \mu \mathrm{M})$, a presumed specific blocker of TRPV2 channels (Table 1), did not affect the sADP $(12.6 \pm 2.8 \mathrm{mV}$ vs $12.7 \pm 2.9 \mathrm{mV} ; p>0.05$, Wilcoxon paired test, $n=5$ cells; Fig. 8 B3). Because of potential side effects of probenecid on pannexin-1 (Ma et al., 2009), the effect of probenecid on the sADP was re-evaluated in the presence of a broad spectrum inhibitor of pannexins, carbenoxolone ( $50 \mu \mathrm{M}$, data not shown), and a more specific blocker of pannexin- 1 channels, mefloquine $(50 \mu \mathrm{M})$. The mean amplitude of the sADP recorded under carbenoxolone and mefloquine did not differ from that recorded under control conditions (control: $12.41 \pm 0.51 \mathrm{mV}, n=126$ vs pannexin-1 inhibitors: $10.57 \pm 0.91 \mathrm{mV}, n=12$; $p>0.05$, Mann-Whitney test). Furthermore, the two inhibitors did not prevent the probenecid-induced potentiation of the $\operatorname{sADP}(10.57 \pm$ $0.91 \mathrm{mV}$ vs $15.60 \pm 1.45 \mathrm{mV} ; p<0.01$, Wilcoxon paired test, $n=$ 12 cells; Fig. 8B4). These data do not support a role of pannexin hemichannels in the generation/modulation of the sADP. Camphor $(10 \mu \mathrm{M})$, a TRPV3 agonist (Table 1), slightly but significantly increased the amplitude of the SADP $(12.3 \pm 0.9 \mathrm{mV}$ vs $14.7 \pm 1.6 \mathrm{mV} ; p<0.05$, Wilcoxon paired test, $n=6$ cells; Fig. $8 C 1)$. However, IPP (200 $\mu \mathrm{M})$, a TRPV3 blocker (Table 1), did not affect the $\operatorname{sADP}(13.4 \pm 3 \mathrm{mV}$ vs $13.5 \pm 3.2 \mathrm{mV} ; p>0.05$, Wilcoxon paired test, $n=4$ cells; Fig. $8 C 2$ ). Finally, the fourth member of the TRPV family does not seem to be involved in the generation/modulation of the sADP as neither $4 \alpha \mathrm{PDD}(10 \mu \mathrm{M}$; Fig. $8 D 1)$ nor $R N-1734$ (50 $\mu \mathrm{M}$; Fig. 8D2), agonist and antagonist 


\section{A $\operatorname{TTX}(1 \mu \mathrm{M})+\operatorname{TEA}(10 \mathrm{mM})$}

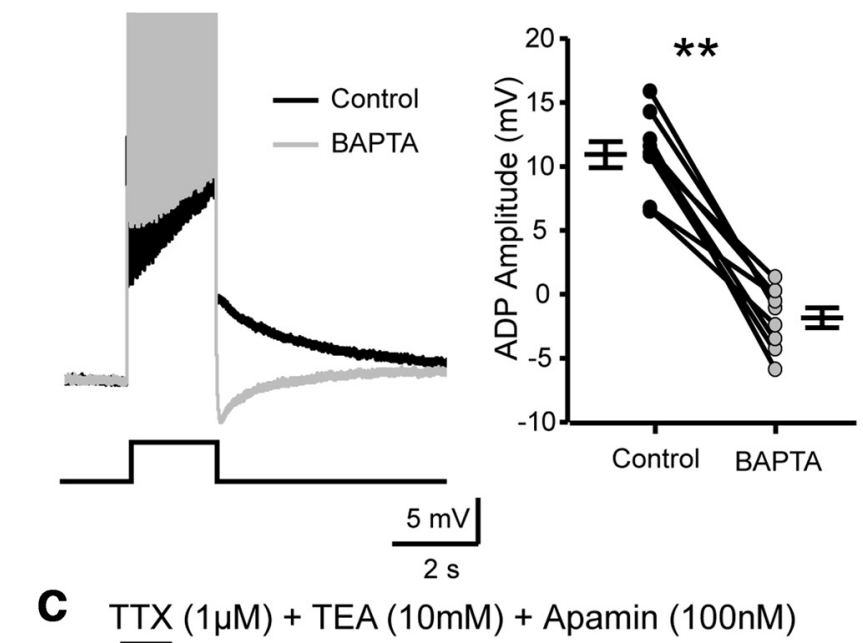

B $\operatorname{TTX}(1 \mu \mathrm{M})+\operatorname{TEA}(10 \mathrm{mM})+$ Apamin $(100 \mathrm{nM})$

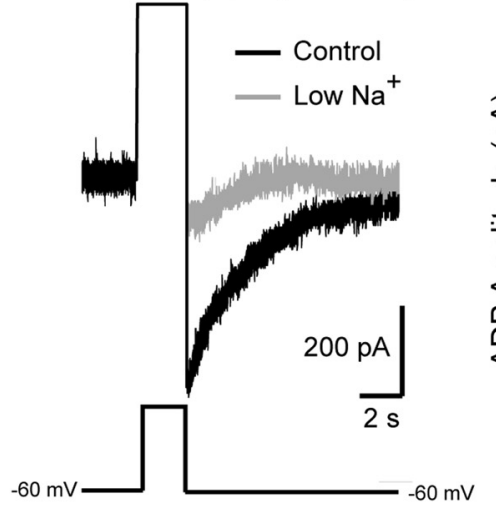

$\mathbf{E}$

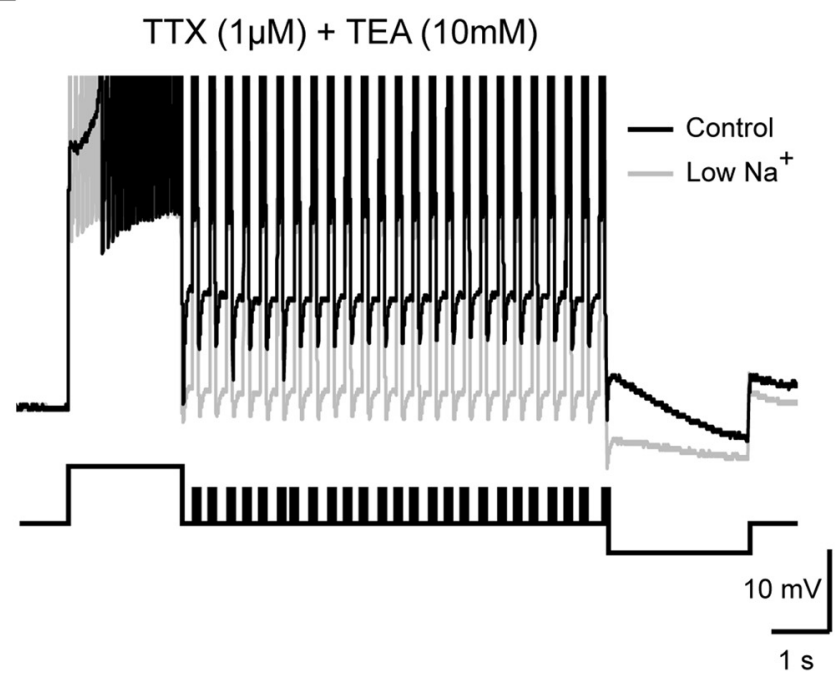

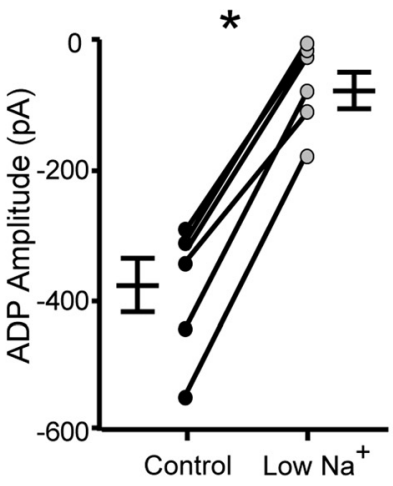

Control Low $\mathrm{Na}^{+}$

D
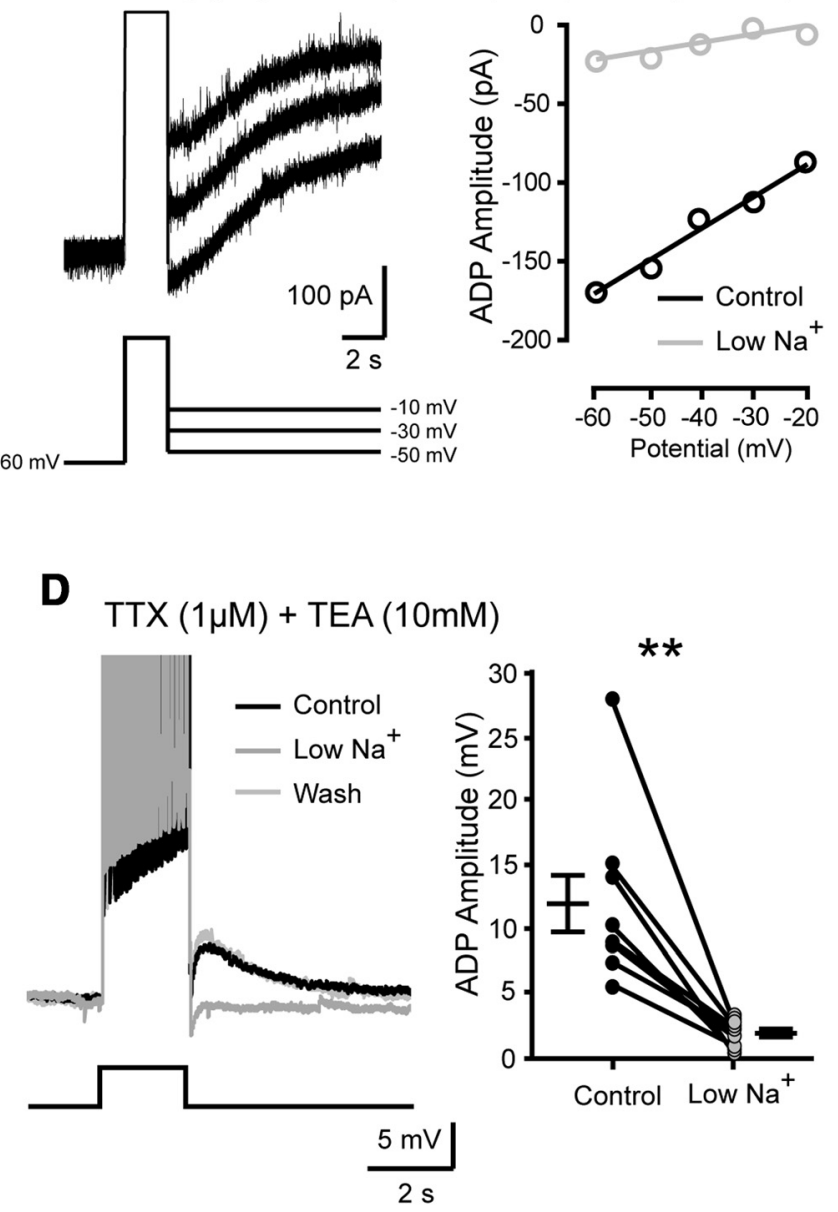

$\mathbf{F}$
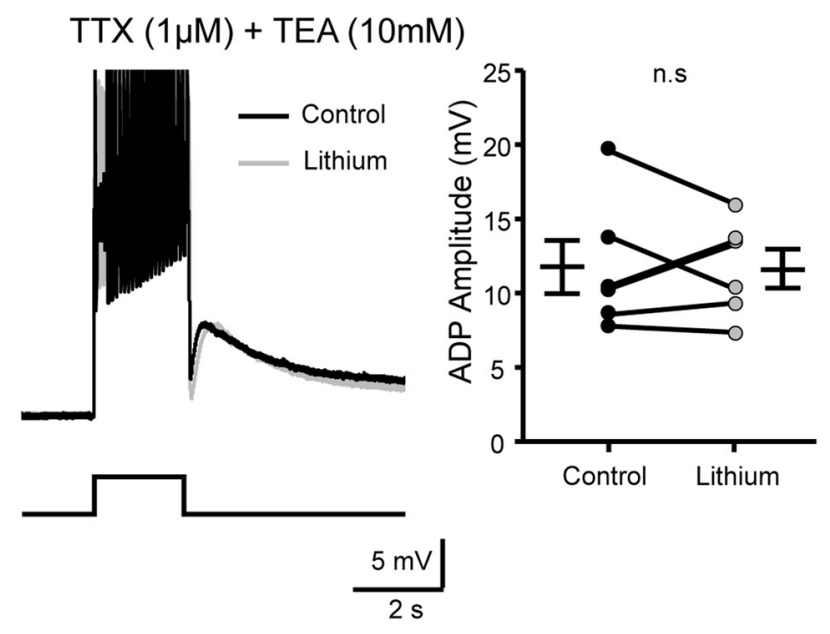

Control Lithium

Figure 6. The SADP and plateau potentials are dependent on $\mathrm{I}_{\mathrm{CaN}}$ that uses $\mathrm{Na}^{+}$as the main charge carrier, not a $\mathrm{Na}^{+} / \mathrm{Ca}^{2+}$ exchanger. $A$, Superimposed voltage traces in response to a $2 \mathrm{~s}$ depolarizing pulse before (black traces) and after (gray traces) chelating the intracellular $\mathrm{Ca}^{2+}$ with BAPTA $(10 \mathrm{~mm})$ in the pipette solution. $\boldsymbol{B}$, Left, Superimposed current traces from a motoneuron recorded under TEA $(10 \mathrm{~mm}), \operatorname{TTX}(1 \mu \mathrm{M})$, and apamin $(100 \mathrm{~nm})$, held at $-60 \mathrm{mV}$, step-depolarized to $+10 \mathrm{mV}$ and then returned to potentials between -60 and $0 \mathrm{mV}$. $0 \mathrm{n}$ the right, $I-V$ relationship of the peak inward tail current plotted against the return potential before (black trace) and after (gray trace) lowering the extracellular concentration of $\mathrm{Na}^{+}$. C, $\boldsymbol{D}$, Superimposed current $(\boldsymbol{C})$ and voltage $(\boldsymbol{D})$ traces in response to a 2 s depolarizing pulse before (black traces) and after (gray traces) lowering the extracellular concentration of $\mathrm{Na}^{+}$. $\boldsymbol{E}$, Superimposed voltage traces from a bistable motoneuron recorded at resting membrane potential in response to a 2 s square pulse followed by a series of brief depolarizing current pulses before (black trace) and after (gray trace) lowering the concentration of $\mathrm{Na}^{+}$. $\boldsymbol{F}$, Superimposed voltage traces in response to a $2 \mathrm{~s}$ depolarizing pulse before (black traces) and after (gray traces) the blockade of the $\mathrm{Na}^{+} / \mathrm{Ca}^{2+}$ exchanger by lithium. $\boldsymbol{A}$, $C, D, F$, Right, Graphs show the mean amplitude of the sADP before and after the drug application. Recordings were made under TTX (1 $\mu \mathrm{M})$ and TEA (10 mM). The apamin (100 nM) was superfused for voltage-clamp recordings. Holding potential, $-60 \mathrm{mV}$. Error bars indicate SEM. ns, Not significant; ${ }^{*} p<0.05$, ${ }^{* *} p<0.01$ (Wilcoxon paired test). 

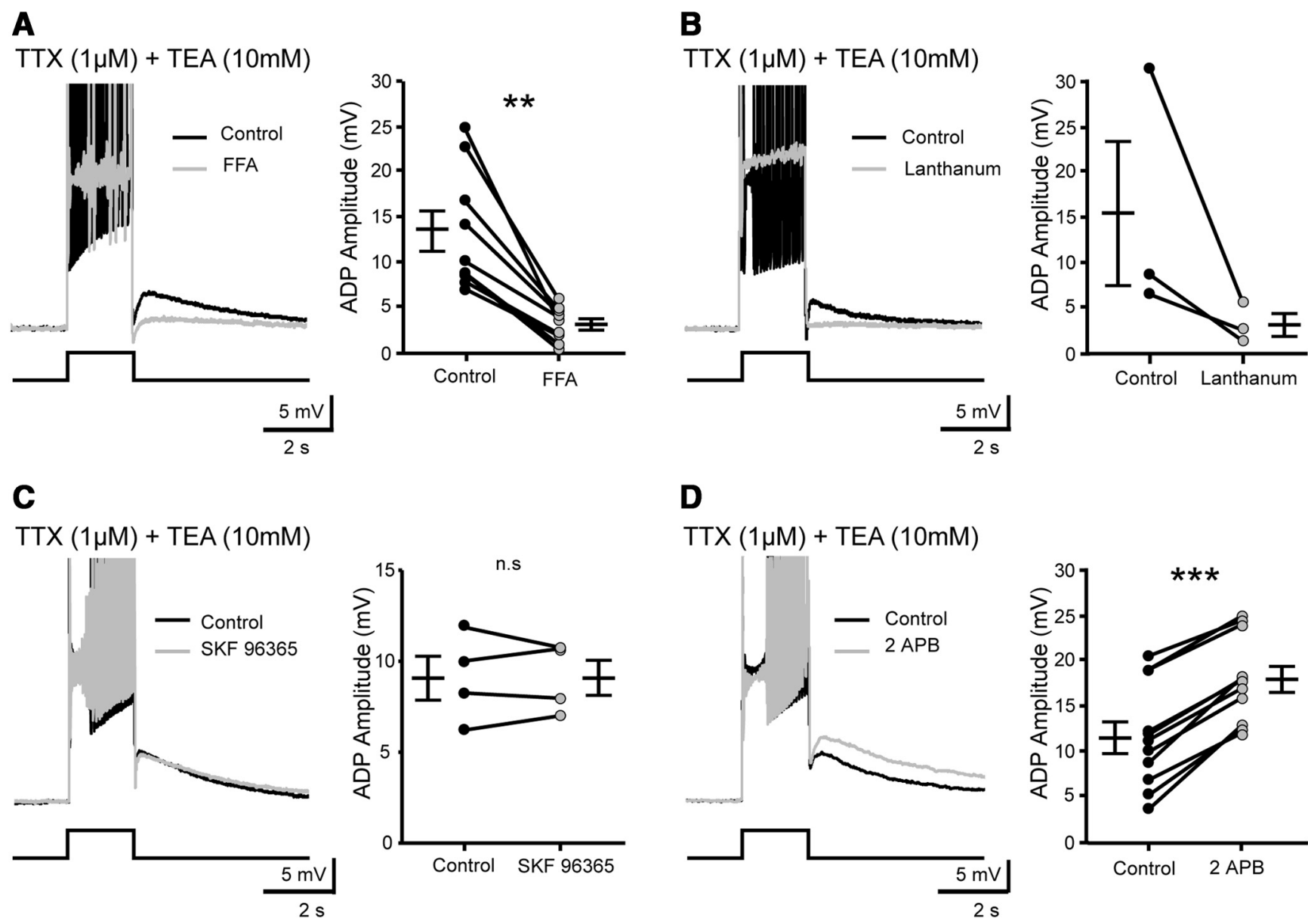

D
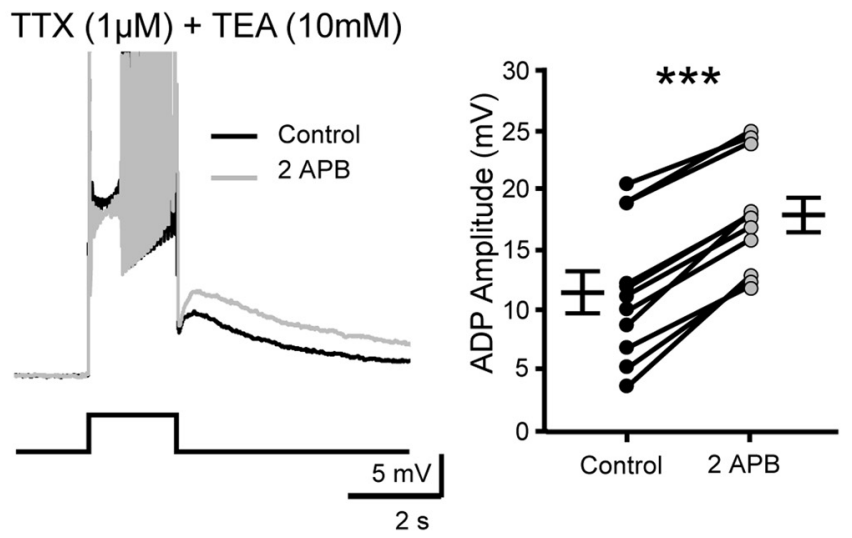

Figure 7. The SADP is upregulated by thermosensitive TRPV cation channels. $A-D$, Superimposed voltage traces in response to a $2 s$ depolarizing pulse before (black traces) and after (gray traces) the addition of: $(\boldsymbol{A})$ flufenamate $(75 \mu \mathrm{M})$ or $(\boldsymbol{B})$ lanthanum $(100 \mu \mathrm{M})$, two broad spectrum TRP channel blockers; (C) SKF 96365, a nonselective TRPC channel blocker (20 $\mu \mathrm{M})$; and (D) 2-APB, a common activator of TRPV channels. Right, Graphs show the mean amplitude of the SADP before and after the drug application. Recordings were made under TTX and TEA. Holding potential, $-60 \mathrm{mV}$. Error bars indicate SEM. ns, Not significant; ${ }^{*} p<0.05,{ }^{* *} p<0.01,{ }^{* * *} p<0.001$ (Wilcoxon paired test).

Table 1. Agonists and antagonists of TRPV

\begin{tabular}{|c|c|c|c|c|c|c|c|c|c|c|c|}
\hline & \multicolumn{2}{|l|}{ TRPV1 } & \multicolumn{2}{|l|}{ TRPV2 } & \multicolumn{2}{|l|}{ TRPV3 } & \multicolumn{2}{|l|}{ TRPV4 } & \multicolumn{2}{|c|}{ Other TRPs } & \multirow[b]{2}{*}{ References } \\
\hline & Agonist & Antagonist & Agonist & Antagonist & Agonist & Antagonist & Agonist & Antagonist & Agonist & Antagonist & \\
\hline Lanthanum & - & + & - & + & - & + & - & + & - & + & (Wu et al., 2010) \\
\hline FFA & - & + & - & + & - & + & - & + & - & + & (Guinamard et al., 2013) \\
\hline $2 A P B$ & + & - & + & - & + & - & - & - & - & + & $\begin{array}{l}\text { (Hu et al., 2004; Harteneck } \\
\text { and Gollasch, 2011) }\end{array}$ \\
\hline Capsazepine & - & + & - & - & - & - & - & - & - & - & (Caterina et al., 1997) \\
\hline Probenecid & - & - & + & - & - & - & - & - & - & - & (Bang et al., 2007) \\
\hline Tranilast & - & - & - & + & - & - & - & - & - & - & (Hisanaga et al., 2009) \\
\hline Camphor & - & - & - & - & + & - & - & - & - & - & (Mogrich et al., 2005) \\
\hline IPP & - & - & - & - & - & + & - & - & - & - & (Bang et al., 2011) \\
\hline $4 \alpha \mathrm{PDD}$ & - & - & - & - & - & - & + & - & - & - & (Watanabe et al., 2002) \\
\hline
\end{tabular}

of TRPV4 channels respectively (Table 1), altered the sADP (for $4 \alpha \mathrm{PDD}: 13.2 \pm 4.4 \mathrm{mV}$ vs $13.2 \pm 4.6 \mathrm{mV}, n=6$ cells; for $\mathrm{RN}$ 1734: $10.3 \pm 1.9 \mathrm{mV}$ vs $10.3 \pm 1.8 \mathrm{mV}, n=3$ cells; $p>0.05$, Wilcoxon paired test).

Activation of TRPV2 channels generates self-sustained firing In contrast to the pharmacological activation of TRPV 3 channels, that of TRPV2 triggered self-sustained firing in motoneurons recorded in normal conditions (in the absence of TTX and TEA; $n=5$ cells; Fig. 9A). Furthermore, when intracellular $\mathrm{Ca}^{2+}$ ions were buffered by means of BAPTA ( $10 \mathrm{~mm})$, bistable behaviors were gradually suppressed ( $n=5$; Fig. 9B). This effect did not result from the indirect blockade of $\mathrm{IK}_{\mathrm{Ca}}$ as apamin did not abolish self-sustained firing $(n=4$; Fig. 9C). In addition to its dependence on intracellular $\mathrm{Ca}^{2+}$ concentration, TRPV2 channels, so 
Agonists

Antagonists

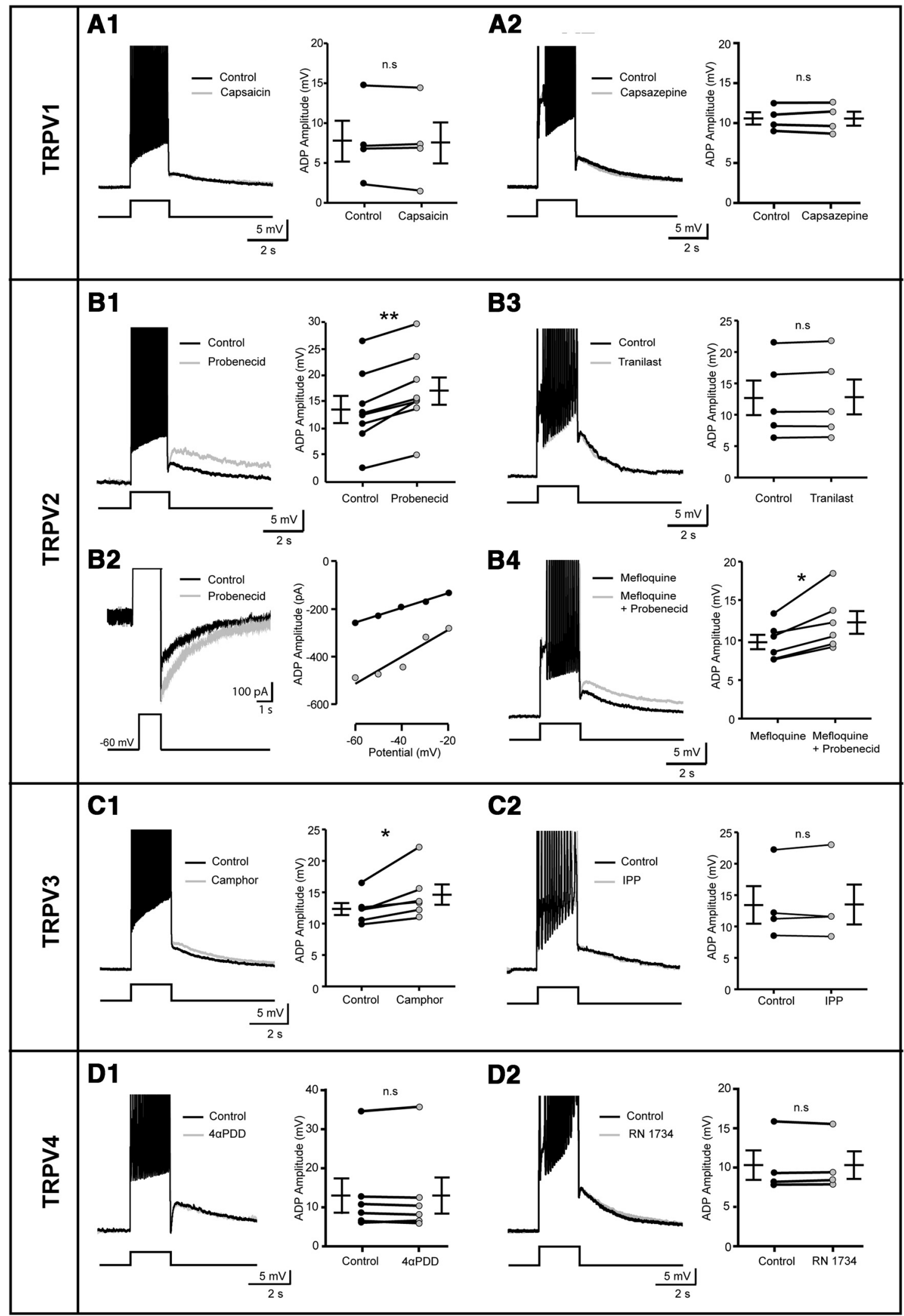

Figure 8. Among TRPV cationic channels, TRPV2 upregulates the SADP. A-D, Superimposed voltage traces in response to a 2 s depolarizing pulse before (black traces) and after (gray traces) the addition of agonists (left in $\boldsymbol{A 1}, \boldsymbol{B} 1, \mathbf{C}$, and $\mathbf{D 1}$ ) or antagonists (right in $\boldsymbol{A 2}, \boldsymbol{B 2}, \mathbf{C}$, and D2) of specific TRPV1 (A), TRPV2 (B), TRPV3 (C), or TRPV4 (D) channels. B2, Left, Superimposed current traces in response to a $2 \mathrm{~s}$ depolarizing pulse before (black traces) and after (gray traces) applying probenecid ( $250 \mu \mathrm{M}$ ). Right, $I-V$ relationship of the peak inward tail current plotted against the return potential. B4, Superimposed current traces in response to a $2 \mathrm{~s}$ depolarizing pulse recorded under mefloquine ( $50 \mu \mathrm{M}$ ) before (black traces) and after (gray traces) applying probenecid ( $250 \mu \mathrm{M}$ ). Recordings were made under TTX and TEA. Holding potential, $-60 \mathrm{mV}$. Error bars indicate SEM. ns, Not significant; ${ }^{*} p<0.05,{ }^{* *} p<0.01$ (Wilcoxon paired test). 


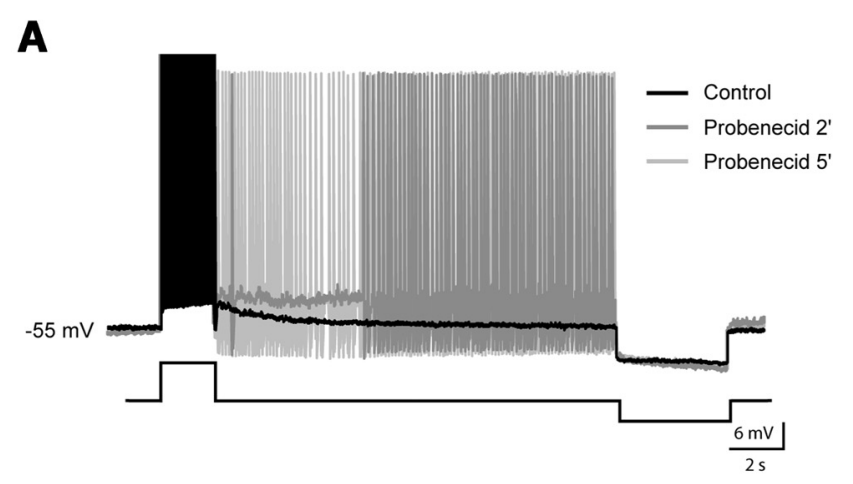

B
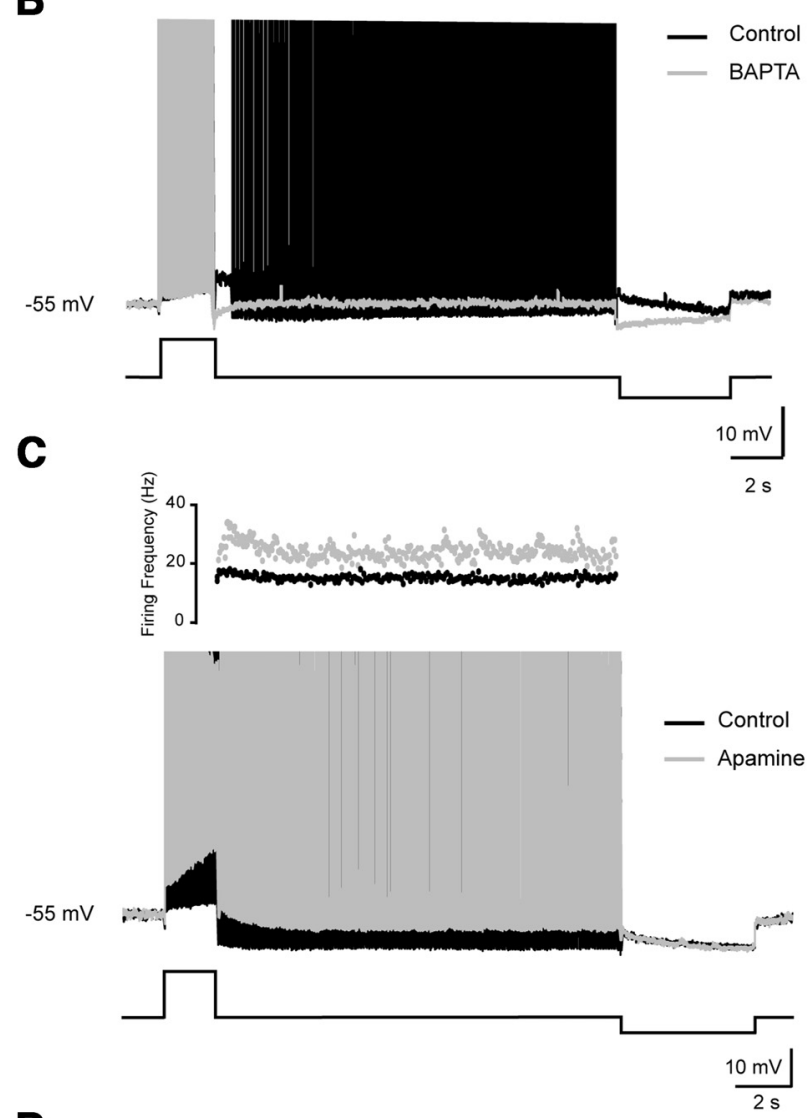

D

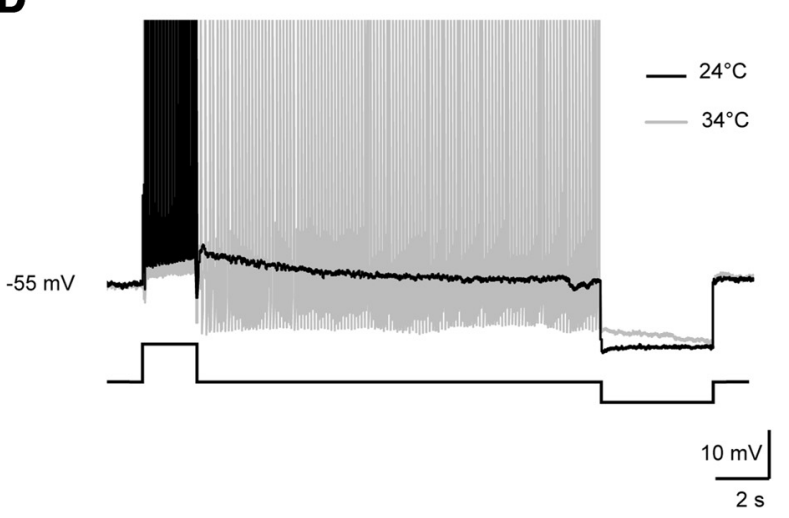

Figure 9. Activation of TRPV2 channels generates self-sustained firing. $A-D$, Superimposed voltage traces recorded in normal saline (without TX and TEA) in response to a 2 s depolarizing pulse before (black traces) and after (gray traces) bath applying probenecid (A), chelating intracellular $\mathrm{Ca}^{2+}$ with BAPTA $(B)$, blocking $\mathrm{IK}_{\mathrm{Ca}_{\mathrm{C}}}$ with apamine $\left(\boldsymbol{C}\right.$, or reducing the temperature of the bath from $34^{\circ} \mathrm{C}$ to $28^{\circ} \mathrm{C}(\boldsymbol{D})$. C, Instantaneous frequency plots are shown on top of intracellular recordings. called thermo-TRPs, are activated by heating (Benham et al., 2003). To further test the functional contribution of TRPV2 channels, we examined whether changes in the temperature were able to affect the generation of bistable behaviors. A decrease of $10^{\circ} \mathrm{C}$, from 34 to $24^{\circ} \mathrm{C}$, induced a reversible loss of self sustained firing in all bistable motoneurons tested ( $n=10$ cells; Fig. 9D). The threshold temperature at which self-sustained firing disappeared was $29.5 \pm 0.6^{\circ} \mathrm{C}(n=10)$. Altogether, these data suggest that TRPV2 channels generate and/or modulate the $\mathrm{I}_{\mathrm{CaN}}$ underlying plateau potentials in lumbar motoneurons.

\section{Discussion}

New insights into mechanisms underlying plateau potentials in spinal motoneurons can be drawn: (1) Bistable properties in motoneurons innervating the triceps surae muscles appear before the acquisition of a quadrupedal stance. (2) The mechanism underlying self-sustained firing involves the interplay of three conductances: L-type $\mathrm{I}_{\mathrm{Ca}}, \mathrm{I}_{\mathrm{NaP}}$, and $\mathrm{I}_{\mathrm{CaN}}$. (3) Plateau potentials use $\mathrm{Na}^{+}$as the main charge carrier flowing through putative cationic TRPV2 channels.

\section{Plateau potentials rely on $\mathrm{I}_{\mathrm{CaN}}$}

In a wide range of invertebrate (Kiehn and Harris-Warrick, 1992; Cattaert et al., 1994; Angstadt and Choo, 1996) and vertebrate neurons (Kiehn and Harris-Warrick, 1992; Fraser and MacVicar, 1996; Russo and Hounsgaard, 1996; Di Prisco et al., 1997; Morisset and Nagy, 1999; Derjean et al., 2005), plateau potentials are generated by noninactivating conductances mediating "persistent inward currents" (PICs). The PICs in motoneurons are composed of $\mathrm{I}_{\mathrm{NaP}}$ (Nishimura et al., 1989; Hsiao et al., 1998; Lee and Heckman, 2001; Li and Bennett, 2003; Powers and Binder, 2003; Tazerart et al., 2007) and calcium components (Schwindt and Crill, 1980; Hounsgaard and Kiehn, 1989; Heckman et al., 2008a; Carlin et al., 2009). PICs generating plateaus in motoneurons of adult cats (Hounsgaard et al., 1984), mice (Carlin et al., 2000b), rats (Li and Bennett, 2003), turtles (Hounsgaard and Mintz, 1988), and frogs (Perrier and Tresch, 2005) are predominantly mediated by L-type calcium channels and to a lesser extent by $\mathrm{I}_{\mathrm{NaP}}$ (Li et al., 2004; Harvey et al., 2006). Although PICs are present in neonatal rodent motoneurons (Gao and ZiskindConhaim, 1998; Tazerart et al., 2007; Pambo-Pambo et al., 2009), plateau potentials had never been revealed during the first postnatal week. Herein, we unmasked such bistability by raising the temperature. Several pieces of evidence support that L-type $\mathrm{Ca}^{2+}$ channels do not provide the main charge carrier for plateau potential. First, dihydropyridines L-type $\mathrm{Ca}^{2+}$ channel blockers did not block plateau potentials reliably. Second, after the intracellular $\mathrm{Ca}^{2+}$ was chelated, $\mathrm{Ca}^{2+}$ spikes evoked by depolarizing current pulses persisted, whereas the SADP and plateau potentials were abolished. Third, removing $\mathrm{Na}^{+}$from the extracellular solution abolished plateau potentials. These results raise $\mathrm{I}_{\mathrm{NaP}}$ as a putative candidate for bistability. However, if $\mathrm{I}_{\mathrm{NaP}}$ appears essential for self-sustained firing (Fig. 3B; Kuo et al., 2006), it does not drive plateau potentials because SADP and plateau potentials are TTX-insensitive (Fig. 6D).

Results from TTX application, intracellular $\mathrm{Ca}^{2+}$ chelation, and $\mathrm{Na}^{+}$substitution suggest a tonic $\mathrm{Na}^{+}$influx through nonselective cationic channels at the source of plateau potentials. Results with FFA and trivalent ions support this assumption but should be interpreted with caution as these agents are broadspectrum ion channel modulators (Reichling and MacDermott, 1991; Guinamard et al., 2013). More convincing evidence is provided by the increase of the SADP by $2-\mathrm{APB}$. This response profile 
points to the activation of TRPV channels (Hu et al., 2004). Several features of TRPV channels are compatible with plateau potentials. First, activation of TRPV channels requires intracellular $\mathrm{Ca}^{2+}$ (Partridge and Swandulla, 1988). Second, TRPV channels are thermosensitive and mediate cell depolarization in response to temperature increases (Benham et al., 2003), and the likelihood to record selfsustained firing increases from 28 to $34^{\circ} \mathrm{C}$ (Fig. 8). Third, as for the windup characteristic of bistable motoneurons, TRPV2and TRPV3-mediated currents display marked sensitization (gradual increase in amplitude) with repeated stimuli (Moqrich et al., 2005; Leffler et al., 2007). Fourth, TRPV2 and TRPV3 channels are expressed in spinal motoneurons (Lewinter et al., 2004; Facer et al., 2007). Fifth, from the application of different TRPV channel openers it appeared that TRPV2 channels are able to trigger plateau potentials. All these properties therefore support the involvement of TRPV2 channels in the generation/modulation of plateau potentials in developing motoneurons. However, tranilast did not alter the sADP (Fig. 8B3). The assumed specificity of the blockade of TRPV2 channels by this compound relies on very little and indirect evidence. Hisanaga et al. (2009) showed that upon stimulation of pancreatic $\beta$-cells with glucose or insulin, TRPV2 translocates to the cell membrane and that this translocation is blocked by tranilast. The translocation of TRPV2 channels can be regulated at many levels and, for instance, a similar blockade of the translocation was also obtained with an inhibitor of phosphatidylinositol 3-kinase or a blocker of the L-type voltage calcium channel. Due to the lack of reliable pharmacological tools, future investigations using genetic tools will be required to determine the precise role of TRPV2 channels in the generation/ modulation of motoneuronal bistability.

\section{The cascade of events underlying plateau firing mode}

In sum, plateau potentials are to a large extent determined by a "ménage à trois" of conductances $\mathrm{I}_{\mathrm{CaN}}, \mathrm{I}_{\mathrm{NaP}}$, and L-type $\mathrm{I}_{\mathrm{Ca}}$. Based on the physiological and pharmacological properties of plateaus, we suggest the following scenario (Fig. 10): (1) Brief membrane depolarization (and subsequent recruitment of $\mathrm{Na}^{+}$-depen-

dent spikes) activates nifedipine-sensitive L-type $\mathrm{Ca}^{2+}$ channels. (2) The resulting $\mathrm{Ca}^{2+}$ entry activates $\mathrm{I}_{\mathrm{CaN}}$ likely through a process involving a $\mathrm{Ca}^{2+}$-induced $\mathrm{Ca}^{2+}$ release (Mejia-Gervacio et al., 2004). (3) After the cation channel has brought the initial sADP close to the threshold of $\mathrm{I}_{\mathrm{NaP}}$, this steady-state inward current promotes repetitive spiking activity. (4) When spikes occur close to each other, the summed sADPs generate a persistent plateau potential that further sustains firing by bringing the membrane potential closer to action potential threshold and so
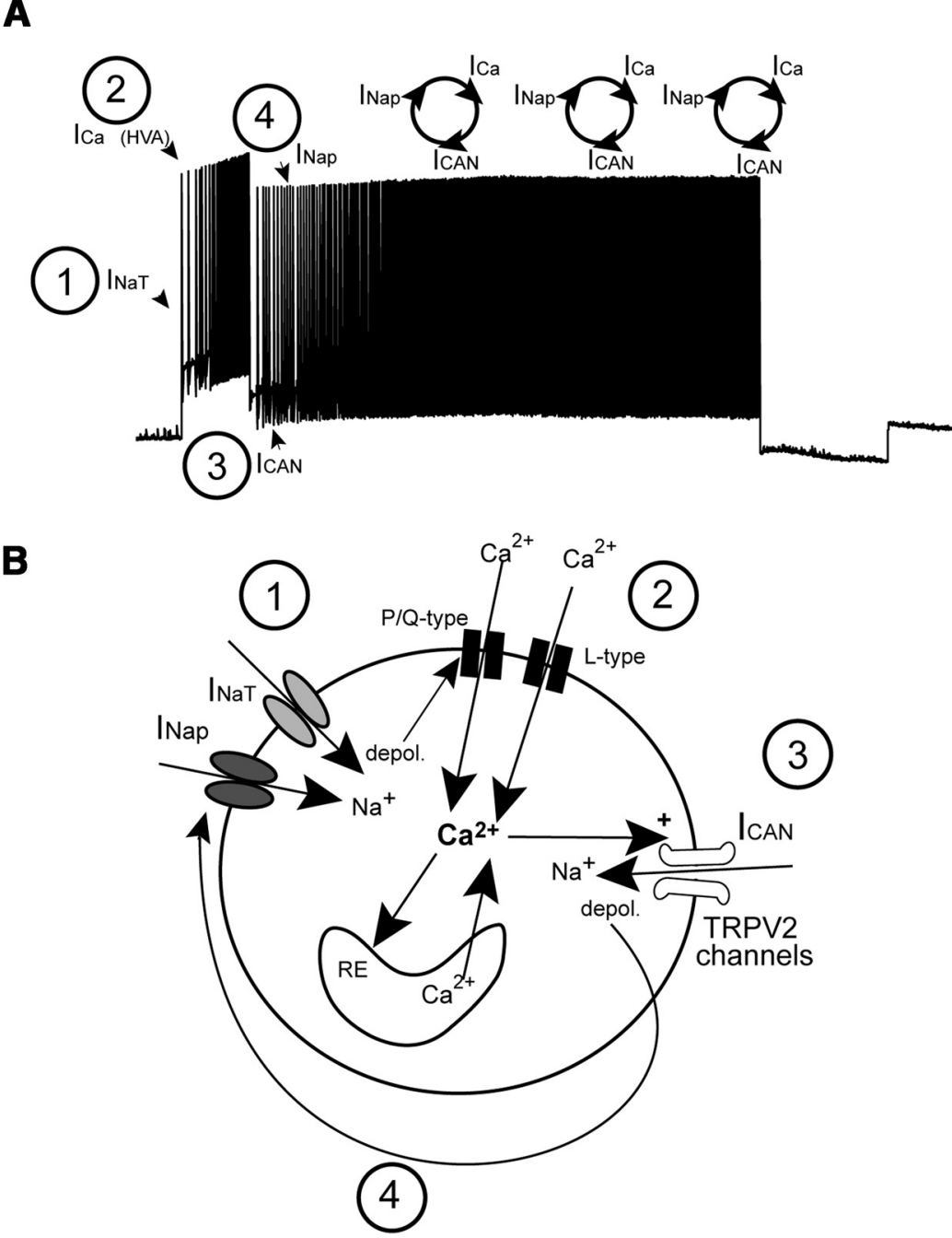

Figure 10. A schematic ménage à trois relationship between currents underlying the different phases of the plateau firing mode. The $\mathrm{Ca}^{2+}$ entry via voltage-dependent $\mathrm{Ca}^{2+}$ current occurs during the train of action potential (step 1 and 2 in $\boldsymbol{A}$ and $\boldsymbol{B}$ ). This increase in ). The positive change in membrane potential opens voltage-dependent persistent $\mathrm{Na}{ }^{+}$current to maintain a train of action potential (step 4 in $\boldsymbol{A}$ and $\boldsymbol{B}$ ). The repetitive spiking activity will then induce $\mathrm{Ca}^{2+}$ entry via voltage-dependent $\mathrm{Ca}^{2+}$ current and so forth.

on. (5) This mechanism ends when an inhibitory input is large enough to break the ménage à trois.

$\mathrm{I}_{\mathrm{CaN}}$ and bistable properties in the CNS

$\mathrm{I}_{\mathrm{CaN}}$ generates plateau potentials in numerous classes of neurons (Zhang et al., 1995; Fraser and MacVicar, 1996; Beurrier et al., 2000; Di Prisco et al., 2000; Lee and Tepper, 2007; Mrejeru et al., 2011). This current has been reported in spinal motoneurons of turtles but, likely due to species differences, plays a minor role in sustaining the inward current during the plateau (Perrier and Hounsgaard, 1999). In the spinal cord, the presence of a plateau potential and $\mathrm{I}_{\mathrm{CaN}}$ is not specific to motoneurons. Neurons in the dorsal horn (Morisset and Nagy, 1999) and the lateral intermediate gray matter (Derjean et al., 2005) exhibit $\mathrm{I}_{\mathrm{CaN}^{-}}$-dependent plateau potentials. Likewise, in motoneurons of the nucleus ambiguous, Rekling and Feldman (1997) provided evidence that $\mathrm{I}_{\mathrm{CaN}}$ contributes to the plateau depolarization. The $\mathrm{I}_{\mathrm{CaN}}$ has been shown to underlie neuronal burst firing in various areas of the CNS (Hasuo et al., 1990; Raggenbass et al., 1997; Beurrier et al., 2000; Thoby-Brisson and Ramirez, 2001; Chang and Kim, 2004; 
Zhu et al., 2004; Del Negro et al., 2005; Jasinski et al., 2013; Tsuruyama et al., 2013).

\section{Comparative aspects}

This report provides evidence that motoneurons innervating the triceps surae muscle exhibit self-sustained firing early after birth in rodents. Differences in recording conditions likely account for the fact that plateau potentials have not been reported earlier in neonatal rodents. Most studies have worked at room temperature or $<28^{\circ} \mathrm{C}$, conditions that prevent the expression of plateau potentials.

Given the strong dependence of plateau potentials on L-type $\mathrm{Ca}^{2+}$ channels in adults, it is possible that the $\mathrm{I}_{\mathrm{CaN}^{-}}$-dependent plateau potential is a transient characteristic at a time when all membrane conductances are not fully functional. Indeed, L-type $\mathrm{Ca}^{2+}$ channels are responsible for a small component of $\mathrm{Ca}^{2+}$ currents in neonatal rat motoneurons (Gao and ZiskindConhaim, 1998) and start to make noticeable contributions to motoneuronal firing only at P7 (Jiang et al., 1999). Alternatively, the ménage à trois we revealed in neonates may be transposed in adults. Blockade of L-type $\mathrm{Ca}^{2+}$ channels in adults may abolish the $\mathrm{I}_{\mathrm{CaN}}$ upstream. In addition, the interpretation that plateau potentials rely on $\mathrm{L}$-type $\mathrm{Ca}^{2+}$ channels in adults may be biased by experimental conditions. Most, if not all, studies investigating the contribution of L-type $\mathrm{Ca}^{2+}$ channels to plateau potentials were done in high concentrations of extracellular $\mathrm{Ca}^{2+}(\geq 2.75$ $\mathrm{mm}$ ), far from the physiological value $(1.2 \mathrm{~mm}$ ) in the CSF (Nicholson et al., 1977; Jones and Keep, 1988; Brocard et al., 2013). In this condition, $\mathrm{Ca}^{2+}$ currents are strongly potentiated (Carlin et al., 2000b, 2009), wheras $\mathrm{I}_{\mathrm{NaP}}$ is inhibited (Tazerart et al., 2008). Therefore, the real contribution of L-type $\mathrm{Ca}^{2+}$ and TRPV2 channels in generating plateau potentials should be reevaluated in adult mammalian motoneurons using physiological concentrations of $\mathrm{Ca}^{2+}$.

\section{Functional significance}

We show that bistability of motoneurons is a powerful cellular mechanism for the transformation of sensory inputs into a motor command. Hounsgaard et al. (1988) emphasized the potential importance of self-sustained firing of motoneurons for the maintenance of posture. Although plateau potentials become dominant in triceps surae motoneurons at birth, animals are unable to weight-bear before the second postnatal week (Westerga and Gramsbergen, 1990). This discrepancy suggests that the expression of plateau properties is not the limiting factor in the development of posture. However, plateau potentials emerged only at temperatures $>30^{\circ} \mathrm{C}$. During the first postnatal week, the body temperature of a pup isolated from its mother does not exceed $30^{\circ} \mathrm{C}$ (Fowler and Kellogg, 1975). A steep increase of the body temperature in the same condition is observed at the beginning of the second postnatal week to reach $34^{\circ} \mathrm{C}$ at $\mathrm{P} 9-\mathrm{P} 10$. Therefore, by regulating the expression of plateaus, the development of thermoregulatory mechanisms may contribute to the late emergence of posture in rodents.

\section{References}

Altman J, Sudarshan K (1975) Postnatal development of locomotion in the laboratory rat. Anim Behav 23:896-920. CrossRef Medline

Angstadt JD, Choo JJ (1996) Sodium-dependent plateau potentials in cultured Retzius cells of the medicinal leech. J Neurophysiol 76:1491-1502. Medline

Bang S, Kim KY, Yoo S, Lee SH, Hwang SW (2007) Transient receptor potential V2 expressed in sensory neurons is activated by probenecid. Neurosci Lett 425:120-125. CrossRef Medline
Bang S, Yoo S, Yang TJ, Cho H, Hwang SW (2011) Isopentenyl pyrophosphate is a novel antinociceptive substance that inhibits TRPV3 and TRPA1 ion channels. Pain 152:1156-1164. CrossRef Medline

Benham CD, Gunthorpe MJ, Davis JB (2003) TRPV channels as temperature sensors. Cell Calcium 33:479-487. CrossRef Medline

Bennett DJ, Hultborn H, Fedirchuk B, Gorassini M (1998) Short-term plasticity in hindlimb motoneurons of decerebrate cats. J Neurophysiol 80: 2038-2045. Medline

Beurrier C, Bioulac B, Hammond C (2000) Slowly inactivating sodium current (INaP) underlies single-spike activity in rat subthalamic neurons. J Neurophysiol 83:1951-1957. Medline

Booth V, Rinzel J (1995) A minimal, compartmental model for a dendritic origin of bistability of motoneuron firing patterns. J Comput Neurosci 2:299-312. CrossRef Medline

Bregman BS (1987) Development of serotonin immunoreactivity in the rat spinal cord and its plasticity after neonatal spinal cord lesions. Brain Res 431:245-263. Medline

Brocard F, Vinay L, Clarac F (1999) Development of hindlimb postural control during the first postnatal week in the rat. Brain Res Dev Brain Res 117:81-89. CrossRef Medline

Brocard F, Shevtsova NA, Bouhadfane M, Tazerart S, Heinemann U, Rybak IA, Vinay L (2013) Activity-dependent changes in extracellular $\mathrm{Ca}^{2+}$ and $\mathrm{K}^{+}$reveal pacemakers in the spinal locomotor-related network. Neuron 77:1047-1054. CrossRef Medline

Brownstone RM (2006) Beginning at the end: repetitive firing properties in the final common pathway. Prog Neurobiol 78:156-172. CrossRef Medline

Bui TV, Ter-Mikaelian M, Bedrossian D, Rose PK (2006) Computational estimation of the distribution of L-type $\mathrm{Ca}^{2+}$ channels in motoneurons based on variable threshold of activation of persistent inward currents. J Neurophysiol 95:225-241. CrossRef Medline

Carlin KP, Jiang Z, Brownstone RM (2000a) Characterization of calcium currents in functionally mature mouse spinal motoneurons. Eur J Neurosci 12:1624-1634. CrossRef Medline

Carlin KP, Jones KE, Jiang Z, Jordan LM, Brownstone RM (2000b) Dendritic L-type calcium currents in mouse spinal motoneurons: implications for bistability. Eur J Neurosci 12:1635-1646. CrossRef Medline

Carlin KP, Bui TV, Dai Y, Brownstone RM (2009) Staircase currents in motoneurons: insight into the spatial arrangement of calcium channels in the dendritic tree. J Neurosci 29:5343-5353. CrossRef Medline

Caterina MJ, Schumacher MA, Tominaga M, Rosen TA, Levine JD, Julius D (1997) The capsaicin receptor: a heat-activated ion channel in the pain pathway. Nature 389:816-824. CrossRef Medline

Cattaert D, Araque A, Buno W, Clarac F (1994) Motor neurons of the crayfish walking system possess TEA-revealed regenerative electrical properties. J Exp Biol 188:339-345. Medline

Cazalets JR, Menard I, Crémieux J, Clarac F (1990) Variability as a characteristic of immature motor systems: an electromyographic study of swimming in the newborn rat. Behav Brain Res 40:215-225. CrossRef Medline

Chang SY, Kim U (2004) Ionic mechanism of long-lasting discharges of action potentials triggered by membrane hyperpolarization in the medial lateral habenula. J Neurosci 24:2172-2181. CrossRef Medline

Clarac F, Brocard F, Vinay L (2004) The maturation of locomotor networks. Prog Brain Res 143:57-66. CrossRef Medline

Collins DF, Burke D, Gandevia SC (2001) Large involuntary forces consistent with plateau-like behavior of human motoneurons. J Neurosci 21: 4059-4065. Medline

Conway BA, Hultborn H, Kiehn O, Mintz I (1988) Plateau potentials in alpha-motoneurones induced by intravenous injection of L-dopa and clonidine in the spinal cat. J Physiol 405:369-384. Medline

Crone C, Hultborn H, Kiehn O, Mazieres L, Wigström H (1988) Maintained changes in motoneuronal excitability by short-lasting synaptic inputs in the decerebrate cat. J Physiol 405:321-343. Medline

Del Negro CA, Morgado-Valle C, Hayes JA, Mackay DD, Pace RW, Crowder EA, Feldman JL (2005) Sodium and calcium current-mediated pacemaker neurons and respiratory rhythm generation. J Neurosci 25:446453. CrossRef Medline

Derjean D, Bertrand S, Nagy F, Shefchyk SJ (2005) Plateau potentials and membrane oscillations in parasympathetic preganglionic neurones and intermediolateral neurones in the rat lumbosacral spinal cord. J Physiol 563:583-596. CrossRef Medline

Di Prisco GV, Pearlstein E, Robitaille R, Dubuc R (1997) Role of sensory- 
evoked NMDA plateau potentials in the initiation of locomotion. Science 278:1122-1125. CrossRef Medline

Di Prisco GV, Pearlstein E, Le Ray D, Robitaille R, Dubuc R (2000) A cellular mechanism for the transformation of a sensory input into a motor command. J Neurosci 20:8169-8176. Medline

Eken T, Hultborn H, Kiehn O (1989) Possible functions of transmittercontrolled plateau potentials in alpha motoneurones. Prog Brain Res 80: 257-267; discussion 239-242. CrossRef Medline

Facer P, Casula MA, Smith GD, Benham CD, Chessell IP, Bountra C, Sinisi M, Birch R, Anand P (2007) Differential expression of the capsaicin receptor TRPV1 and related novel receptors TRPV3, TRPV4 and TRPM8 in normal human tissues and changes in traumatic and diabetic neuropathy. BMC Neurol 7:11. CrossRef Medline

Fady JC, Jamon M, Clarac F (1998) Early olfactory-induced rhythmic limb activity in the newborn rat. Brain Res Dev Brain Res 108:111-123. CrossRef Medline

Fowler SJ, Kellogg C (1975) Ontogeny of thermoregulatory mechanisms in the rat. J Comp Physiol Psychol 89:738-746. CrossRef Medline

Fraser DD, MacVicar BA (1996) Cholinergic-dependent plateau potential in hippocampal CA1 pyramidal neurons. J Neurosci 16:4113-4128. Medline

Friedman A, Arens J, Heinemann U, Gutnick MJ (1992) Slow depolarizing afterpotentials in neocortical neurons are sodium and calciumdependent. Neurosci Lett 135:13-17. CrossRef Medline

Gao BX, Ziskind-Conhaim L (1998) Development of ionic currents underlying changes in action potential waveforms in rat spinal motoneurons. J Neurophysiol 80:3047-3061. Medline

Gorassini MA, Bennett DJ, Yang JF (1998) Self-sustained firing of human motor units. Neurosci Lett 247:13-16. CrossRef Medline

Gorassini M, Bennett DJ, Kiehn O, Eken T, Hultborn H (1999) Activation patterns of hindlimb motor units in the awake rat and their relation to motoneuron intrinsic properties. J Neurophysiol 82:709-717. Medline

Grillner S, Zangger P (1975) How detailed is the central pattern generation for locomotion? Brain Res 88:367-371. CrossRef Medline

Guinamard R, Simard C, Del Negro C (2013) Flufenamic acid as an ion channel modulator. Pharmacol Ther 138:272-284. CrossRef Medline

Harteneck C, Gollasch M (2011) Pharmacological modulation of diacylglycerol-sensitive TRPC3/6/7 channels. Curr Pharm Biotechnol 12: 35-41. CrossRef Medline

Harvey PJ, Li X, Li Y, Bennett DJ (2006) 5-HT2 receptor activation facilitates a persistent sodium current and repetitive firing in spinal motoneurons of rats with and without chronic spinal cord injury. J Neurophysiol 96:1158-1170. CrossRef Medline

Hasuo H, Phelan KD, Twery MJ, Gallagher JP (1990) A calcium-dependent slow afterdepolarization recorded in rat dorsolateral septal nucleus neurons in vitro. J Neurophysiol 64:1838-1846. Medline

Heckman CJ, Lee RH, Brownstone RM (2003) Hyperexcitable dendrites in motoneurons and their neuromodulatory control during motor behavior. Trends Neurosci 26:688-695. CrossRef Medline

Heckman CJ, Hyngstrom AS, Johnson MD (2008a) Active properties of motoneurone dendrites: diffuse descending neuromodulation, focused local inhibition. J Physiol 586:1225-1231. CrossRef Medline

Heckman CJ, Johnson M, Mottram C, Schuster J (2008b) Persistent inward currents in spinal motoneurons and their influence on human motoneuron firing patterns. Neuroscientist 14:264-275. CrossRef Medline

Hisanaga E, Nagasawa M, Ueki K, Kulkarni RN, Mori M, Kojima I (2009) Regulation of calcium-permeable TRPV2 channel by insulin in pancreatic beta-cells. Diabetes 58:174-184. CrossRef Medline

Hounsgaard J, Kiehn O (1989) Serotonin-induced bistability of turtle motoneurones caused by a nifedipine-sensitive calcium plateau potential. J Physiol 414:265-282. Medline

Hounsgaard J, Kiehn O (1993) Calcium spikes and calcium plateaux evoked by differential polarization in dendrites of turtle motoneurones in vitro. J Physiol 468:245-259. Medline

Hounsgaard J, Mintz I (1988) Calcium conductance and firing properties of spinal motoneurones in the turtle. J Physiol 398:591-603. Medline

Hounsgaard J, Hultborn H, Jespersen B, Kiehn O (1984) Intrinsic membrane properties causing a bistable behaviour of alpha-motoneurones. Exp Brain Res 55:391-394. Medline

Hounsgaard J, Hultborn H, Jespersen B, Kiehn O (1988) Bistability of alpha-motoneurones in the decerebrate cat and in the acute spinal cat after intravenous 5-hydroxytryptophan. J Physiol 405:345-367. Medline
Hsiao CF, Del Negro CA, Trueblood PR, Chandler SH (1998) Ionic basis for serotonin-induced bistable membrane properties in guinea pig trigeminal motoneurons. J Neurophysiol 79:2847-2856. Medline

Hu HZ, Gu Q, Wang C, Colton CK, Tang J, Kinoshita-Kawada M, Lee LY, Wood JD, Zhu MX (2004) 2-aminoethoxydiphenyl borate is a common activator of TRPV1, TRPV2, and TRPV3. J Biol Chem 279:35741-35748. CrossRef Medline

Hultborn H, Wigström H, Wängberg B (1975) Prolonged activation of soleus motoneurones following a conditioning train in soleus Ia afferents: a case for a reverberating loop? Neurosci Lett 1:147-152. CrossRef Medline

Jasinski PE, Molkov YI, Shevtsova NA, Smith JC, Rybak IA (2013) Sodium and calcium mechanisms of rhythmic bursting in excitatory neural networks of the pre-Bötzinger complex: a computational modelling study. Eur J Neurosci 37:212-230. CrossRef Medline

Jiang Z, Rempel J, Li J, Sawchuk MA, Carlin KP, Brownstone RM (1999) Development of L-type calcium channels and a nifedipine-sensitive motor activity in the postnatal mouse spinal cord. Eur J Neurosci 11:34813487. CrossRef Medline

Jones HC, Keep RF (1988) Brain fluid calcium concentration and response to acute hypercalcaemia during development in the rat. J Physiol 402: 579-593. Medline

Kiehn O, Eken T (1997) Prolonged firing in motor units: evidence of plateau potentials in human motoneurons? J Neurophysiol 78:3061-3068. Medline

Kiehn O, Eken T (1998) Functional role of plateau potentials in vertebrate motor neurons. Curr Opin Neurobiol 8:746-752. CrossRef Medline

Kiehn O, Harris-Warrick RM (1992) Serotonergic stretch receptors induce plateau properties in a crustacean motor neuron by a dual-conductance mechanism. J Neurophysiol 68:485-495. Medline

Kuo JJ, Lee RH, Zhang L, Heckman CJ (2006) Essential role of the persistent sodium current in spike initiation during slowly rising inputs in mouse spinal neurones. J Physiol 574:819-834. CrossRef Medline

Lee CR, Tepper JM (2007) A calcium-activated nonselective cation conductance underlies the plateau potential in rat substantia nigra GABAergic neurons. J Neurosci 27:6531-6541. CrossRef Medline

Lee RH, Heckman CJ (1998) Bistability in spinal motoneurons in vivo: systematic variations in persistent inward currents. J Neurophysiol 80:583593. Medline

Lee RH, Heckman CJ (2001) Essential role of a fast persistent inward current in action potential initiation and control of rhythmic firing. J Neurophysiol 85:472-475. Medline

Leffler A, Linte RM, Nau C, Reeh P, Babes A (2007) A high-threshold heatactivated channel in cultured rat dorsal root ganglion neurons resembles TRPV2 and is blocked by gadolinium. Eur J Neurosci 26:12-22. CrossRef Medline

Lewinter RD, Skinner K, Julius D, Basbaum AI (2004) Immunoreactive TRPV-2 (VRL-1), a capsaicin receptor homolog, in the spinal cord of the rat. J Comp Neurol 470:400-408. CrossRef Medline

Li Y, Bennett DJ (2003) Persistent sodium and calcium currents cause plateau potentials in motoneurons of chronic spinal rats. J Neurophysiol 90:857-869. CrossRef Medline

Li Y, Gorassini MA, Bennett DJ (2004) Role of persistent sodium and calcium currents in motoneuron firing and spasticity in chronic spinal rats. J Neurophysiol 91:767-783. CrossRef Medline

Ma W, Hui H, Pelegrin P, Surprenant A (2009) Pharmacological characterization of pannexin- 1 currents expressed in mammalian cells. J Pharmacol Exp Ther 328:409-418. CrossRef Medline

Mandadi S, Nakanishi ST, Takashima Y, Dhaka A, Patapoutian A, McKemy DD, Whelan PJ (2009) Locomotor networks are targets of modulation by sensory transient receptor potential vanilloid 1 and transient receptor potential melastatin 8 channels. Neuroscience 162:1377-1397. CrossRef Medline

Mejia-Gervacio S, Hounsgaard J, Diaz-Muñoz M (2004) Roles of ryanodine and inositol triphosphate receptors in regulation of plateau potentials in turtle spinal motoneurons. Neuroscience 123:123-130. CrossRef Medline

Montell C (2005) The TRP superfamily of cation channels. Sci STKE 2005: re3. CrossRef Medline

Moqrich A, Hwang SW, Earley TJ, Petrus MJ, Murray AN, Spencer KS, Andahazy M, Story GM, Patapoutian A (2005) Impaired thermosensation in mice lacking TRPV3, a heat and camphor sensor in the skin. Science 307:1468-1472. CrossRef Medline 
Moran MM, Xu H, Clapham DE (2004) TRP ion channels in the nervous system. Curr Opin Neurobiol 14:362-369. CrossRef Medline

Morisset V, Nagy F (1999) Ionic basis for plateau potentials in deep dorsal horn neurons of the rat spinal cord. J Neurosci 19:7309-7316. Medline

Mrejeru A, Wei A, Ramirez JM (2011) Calcium-activated nonselective cation currents are involved in generation of tonic and bursting activity in dopamine neurons of the substantia nigra pars compacta. J Physiol 589: 2497-2514. CrossRef Medline

Nicholson C, Bruggencate GT, Steinberg R, Stöckle H (1977) Calcium modulation in brain extracellular microenvironment demonstrated with ionselective micropipette. Proc Natl Acad Sci U S A 74:1287-1290. CrossRef Medline

Nishimura Y, Schwindt PC, Crill WE (1989) Electrical properties of facial motoneurons in brainstem slices from guinea pig. Brain Res 502:127-142. CrossRef Medline

Pambo-Pambo A, Durand J, Gueritaud JP (2009) Early excitability changes in lumbar motoneurons of transgenic SOD1G85R and SOD1G(93A-low) mice. J Neurophysiol 102:3627-3642. CrossRef Medline

Partridge LD, Swandulla D (1988) Calcium-activated nonspecific cation channels. Trends Neurosci 11:69-72. CrossRef Medline

Perrier JF, Delgado-Lezama R (2005) Synaptic release of serotonin induced by stimulation of the raphe nucleus promotes plateau potentials in spinal motoneurons of the adult turtle. J Neurosci 25:7993-7999. CrossRef Medline

Perrier JF, Hounsgaard J (1999) Ca(2+)-activated nonselective cationic current $(\mathrm{I}(\mathrm{CAN}))$ in turtle motoneurons. J Neurophysiol 82:730-735. Medline

Perrier JF, Hounsgaard J (2000) Development and regulation of response properties in spinal cord motoneurons. Brain Res Bull 53:529-535. CrossRef Medline

Perrier JF, Tresch MC (2005) Recruitment of motor neuronal persistent inward currents shapes withdrawal reflexes in the frog. J Physiol 562:507520. CrossRef Medline

Powers RK, Binder MD (2003) Persistent sodium and calcium currents in rat hypoglossal motoneurons. J Neurophysiol 89:615-624. Medline

Raggenbass M, Pierson P, Metzger D, Alberi S (1997) Action of a metabotropic glutamate receptor agonist in rat lateral septum: induction of a sodium-dependent inward aftercurrent. Brain Res 776:75-87. CrossRef Medline

Rajaofetra N, Sandillon F, Geffard M, Privat A (1989) Pre- and post-natal ontogeny of serotonergic projections to the rat spinal cord. J Neurosci Res 22:305-321. CrossRef Medline

Rajaofetra N, Poulat P, Marlier L, Geffard M, Privat A (1992) Pre- and postnatal development of noradrenergic projections to the rat spinal cord: an immunocytochemical study. Brain Res Dev Brain Res 67:237-246. CrossRef Medline

Reichling DB, MacDermott AB (1991) Lanthanum actions on excitatory amino acid-gated currents and voltage-gated calcium currents in rat dorsal horn neurons. J Physiol 441:199-218. Medline

Rekling JC and Feldman JL (1997) Calcium-dependent plateau potentials in rostral ambiguus neurons in the newborn mouse brain stem in vitro. J Neurophysiol 78:2483-2492.

Reuter H, Porzig H (1995) Localization and functional significance of the $\mathrm{Na}+/ \mathrm{Ca}^{2+}$ exchanger in presynaptic boutons of hippocampal cells in culture. Neuron 15:1077-1084. CrossRef Medline

Russo RE, Hounsgaard J (1996) Plateau-generating neurones in the dorsal horn in an in vitro preparation of the turtle spinal cord. J Physiol 493:3954. Medline

Sadlaoud K, Tazerart S, Brocard C, Jean-Xavier C, Portalier P, Brocard F, Vinay L, Bras H (2010) Differential plasticity of the GABAergic and glycinergic synaptic transmission to rat lumbar motoneurons after spinal cord injury. J Neurosci 30:3358-3369. CrossRef Medline

Schwindt PC, Crill WE (1980) Properties of a persistent inward current in normal and TEA-injected motoneurons. J Neurophysiol 43:1700-1724. Medline

Tazerart S, Viemari JC, Darbon P, Vinay L, Brocard F (2007) Contribution of persistent sodium current to locomotor pattern generation in neonatal rats. J Neurophysiol 98:613-628. CrossRef Medline

Tazerart S, Vinay L, Brocard F (2008) The persistent sodium current generates pacemaker activities in the central pattern generator for locomotion and regulates the locomotor rhythm. J Neurosci 28:8577-8589. CrossRef Medline

Thoby-Brisson M, Ramirez JM (2001) Identification of two types of inspiratory pacemaker neurons in the isolated respiratory neural network of mice. J Neurophysiol 86:104-112. Medline

Tsuruyama K, Hsiao CF, Chandler SH (2013) Participation of a persistent sodium current and calcium-activated non-specific cationic current to burst generation in trigeminal principal sensory neurons. J Neurophysiol, in press. CrossRef Medline

Vinay L, Brocard F, Clarac F (2000a) Differential maturation of motoneurons innervating ankle flexor and extensor muscles in the neonatal rat. Eur J Neurosci 12:4562-4566. CrossRef Medline

Vinay L, Brocard F, Pflieger JF, Simeoni-Alias J, Clarac F (2000b) Perinatal development of lumbar motoneurons and their inputs in the rat. Brain Res Bull 53:635-647. CrossRef Medline

Vinay L, Brocard F, Clarac F, Norreel JC, Pearlstein E, Pflieger JF (2002) Development of posture and locomotion: an interplay of endogenously generated activities and neurotrophic actions by descending pathways. Brain Res Rev 40:118-129. CrossRef Medline

Vincent F, Acevedo A, Nguyen MT, Dourado M, DeFalco J, Gustafson A, Spiro P, Emerling DE, Kelly MG, Duncton MA (2009) Identification and characterization of novel TRPV4 modulators. Biochem Biophys Res Commun 389:490-494. CrossRef Medline

Watanabe H, Davis JB, Smart D, Jerman JC, Smith GD, Hayes P, Vriens J, Cairns W, Wissenbach U, Prenen J, Flockerzi V, Droogmans G, Benham CD, Nilius B (2002) Activation of TRPV4 channels (hVRL-2/mTRP12) by phorbol derivatives. J Biol Chem 277:13569-13577. CrossRef Medline

Westerga J, Gramsbergen A (1990) The development of locomotion in the rat. Brain Res Dev Brain Res 57:163-174. CrossRef Medline

Wu LJ, Sweet TB, Clapham DE (2010) International union of basic and clinical pharmacology: LXXVI. Current progress in the mammalian TRP ion channel family. Pharmacol Rev 62:381-404. CrossRef Medline

Yellen G (1982) Single $\mathrm{Ca}^{2+}$-activated nonselective cation channels in neuroblastoma. Nature 296:357-359. CrossRef Medline

Zhang B, Wootton JF, Harris-Warrick RM (1995) Calcium-dependent plateau potentials in a crab stomatogastric ganglion motor neuron: II. Calcium-activated slow inward current. J Neurophysiol 74:1938-1946. Medline

Zhu ZT, Munhall A, Shen KZ, Johnson SW (2004) Calcium-dependent subthreshold oscillations determine bursting activity induced by $\mathrm{N}$-methyl-D-aspartate in rat subthalamic neurons in vitro. Eur J Neurosci 19:1296-1304. CrossRef Medline 